\title{
A decade of plant proteomics and mass spectrometry: Translation of technical advancements to food security and safety issues
}

Ganesh Kumar Agrawal, Abhijit Sarkar, Pier Giorgio Righetti, Romina Pedreschi, Sebastien Carpentier, Tai Wang, Bronwyn J. Barkla, Ajay Kohli, Bongani Kaiser Ndimba, Natalia V. Bykova, Christof Rampitsch, Lello Zolla, Mohamed Suhail Rafudeen, Rainer Cramer, Laurence Veronique Bindschedler, Nikolaos Tsakirpaloglou, Roya Janeen Ndimba, Jill M. Farrant, Jenny Renaut, Dominique Job, Shoshi Kikuchi and Randeep Rakwal

\begin{abstract}
Tremendous progress in plant proteomics driven by mass spectrometry (MS) techniques has been made since 2000 when few proteomics reports were published and plant proteomics was in its infancy. These achievements include the refinement of existing techniques and the search for new techniques to address food security, safety, and health issues. It is projected that in 2050, the world's population will reach 9-12 billion people demanding a food production increase of 34-70\% (FAO, 2009) from today's food production. Provision of food in a sustainable and environmentally committed manner for such a demand without threatening natural resources, requires that agricultural production increases significantly and that postharvest handling and food manufacturing systems become more efficient requiring lower energy expenditure, a decrease in postharvest losses, less waste generation and food with longer shelf life. There is also a need to look for alternative protein sources to animal based (i.e., plant based) to be able to fulfill the increase in protein demands by 2050. Thus, plant biology has a critical role to play as a science capable of addressing such challenges. In this review, we discuss proteomics especially MS, as a platform, being utilized in plant biology research for the past 10 years having the potential to expedite the process of understanding plant biology for human benefits. The increasing application of proteomics technologies in food security, analysis, and safety is emphasized in this review. But, we are aware that no unique approach/technology is capable to address the global food issues. Proteomics-generated information/resources must be integrated and correlated with other omics-based approaches, information, and conventional programs to ensure sufficient food and resources for human development now and in the future
\end{abstract}

\section{Introduction}

Genome sequencing of plants in the 21st century will help to drive a revolution in how we approach issues of food security, safety, and human health. A few plants have already been sequenced and annotated, such as Arabidopsis and rice, and many more are in the pipeline (Feuillet et al., 2010). Particularly, crop genome sequencing is 
bringing a paradigm shift in the approach to plant biology and crop breeding to meet future global food demand through crop improvement (Flavell, 2010). The information from plant genomes enables the use of high-throughput technologies [such as transcriptomics (gene expression), proteomics (protein expression), and metabolomics (metabolites)] providing a platform to systematically reveal the function of each gene in the genome in combination with other functional genomics tools (Fukushima et al., 2009; Weckwerth, 2011). These technologies are playing an important role in: (i) better understanding biology at the whole plant level, (ii) expediting the process of high-throughput development of molecular markers to assist crop improvement through a combination of modern technology and breeding programs, (iii) developing plant biomarkers for human health and food security, and (iv) food analysis and safety issues.

In the present review, we envision a united approach towards the solution of global food security and safety, focusing mainly on the potential of "plant proteomics and mass spectrometry (MS)" advances, the exploitation of which can increase the present agriculture capacity to feed the world of tomorrow. As the content of this review is broad, encompassing multiple research disciplines, we provide a glimpse on advancements of proteomics and MS technology in plants in the past decade followed by some examples of their utilization in addressing various issues of food security, analysis, safety, and human health/nutrition. We also briefly discuss the importance of integrating the proteomics-generated information with other scientific disciplines (such as functional genomics, biotechnology, and molecular breeding) and various scientific and non-scientific organizations for food security.

\section{Plant proteomics andmass spectrometry: a decade}

\section{A. Historical Perspectives: Then and Now}

In 2015, it will be 40 years since the advent of proteomics, revolutionized via the introduction of two-dimensional gel electrophoresis (2-DGE) (Klose, 1975; O'Farrell, 1975; Scheele, 1975) and later refined with the introduction of immobilized $\mathrm{pH}$ gradients (IPGs) (Bjellqvist et al., 1982; Righetti et al., 2008; Gianazza \& Righetti, 2009; Görg et al., 2009) and MS (Aebersold \& Mann, 2003; Yates, Ruse, \& Nakorchevsky, 2009). Forty years can be considered a long time, but the fact is that the study of proteins within the term proteomics (Wilkins et al., 1995) is quite young, fluid, and diversifying as a technology. Being part of the three young highthroughput omics technologies of genomics (transcriptomics), proteomics, and metabolomics, which are now, allied to high-throughput phenotyping (phenomics), and being amalgamated into the field of systems biology (Ward \& White, 2002; Bradshaw \& Burlingame, 2005; Bradshaw, 2008; Souchelnytskyi, 2008; Coruzzi, Rodrigo, \& Guttierrez, 2009). The relatively younger face of plant proteomics can be realized when we see its wide-spread application in isolation, identification \& cataloguing of proteins, and addressing/answering biological questions from 2000 to now, more than a decade of research in plant proteomics (for reviews and books see, 
Finnie, 2006; Samaj \& Thelen, 2007; Thiellement, 2007; Agrawal \& Rakwal, 2008a; Ranjithakumari, 2008; Weckwerth et al., 2008; Agrawal et al., 2011) (Fig. 1).

As per publications on plant proteomics in PubMed, the progress in plant proteomics can be divided into phases: pre, initial, and progressive (Fig. 1). The prestage can be considered the beginning of proteomics where 1(one)-DGE and 2-DGE techniques were applied to separate proteins and their identification using $N$-terminal Edman sequencing. The initial stage started with the genome revolution in the year 2000 onwards. Since the publication of the draft genome sequences of two plants, Arabidopsis thaliana (weed and dicot model) (The Arabidopsis Genome Initiative, 2000) and rice (Oryza sativa L., cereal crop and monocot model: Goff et al., 2002; Yu et al., 2002) in 2000 and 2002, respectively, plant proteomics research has seen a rapid growth. In this initial phase we also could see an effort by the Arabidopsis scientific community to start working toward the proteome of this model plant via the establishment of a Multinational Arabidopsis Steering Committee Proteomics subcommittee (MASP, www.masc-proteomics.org).

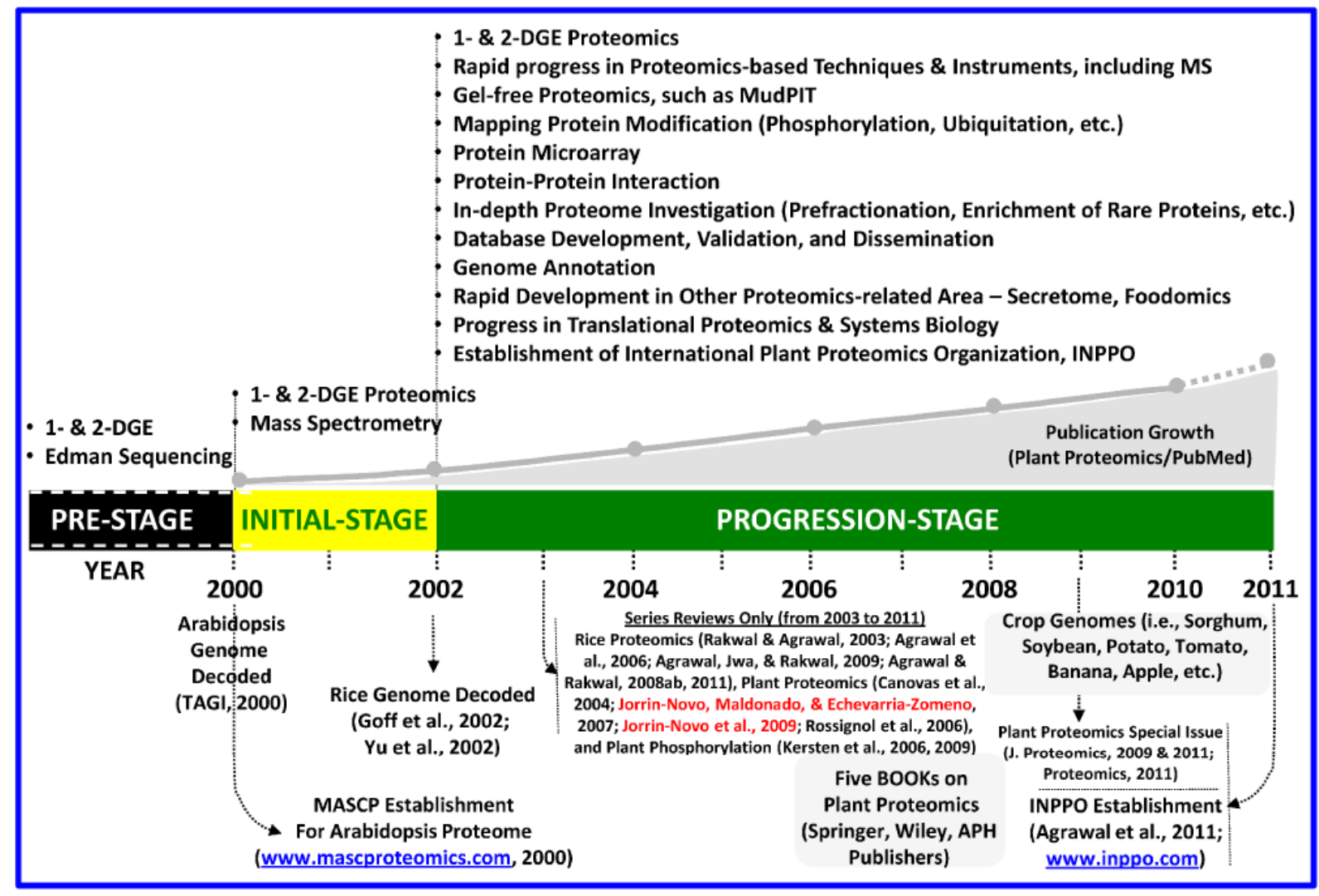

FIGURE 1. Timeline of plant proteomics development. Details are in the main text.

Since then, plant proteomics has moved into the progression stage, where researchers have been involved in enriching the scientific community by concerted efforts to publish reviews in series on rice, plants, and protein phosphorylation and publication of five books in plant proteomics. The initial years of this decade also saw the 
development of an idea on a global initiative on plant proteomics that led to the establishment of the International Plant Proteomics Organization (INPPO, www.inppo.com). With more plant genomes being sequenced, from model to nonmodels (Feuillet et al., 2010; Agrawal et al., 2011), there is no turning back to the utilization of proteomics approaches in various aspects of plant biology research.

The biggest hurdles faced by the scientific community and the population in general are the issues of food security, human health, and our changing environment, and dealing with these issues is one of the visions behind the global movement on plant proteomics, starting from Arabidopsis (Jones et al., 2008; Wienkoop, Baginsky, \& Weckwerth, 2010) and MASCP in the early 2000s to INPPO in 2011. At INPPO, we have defined ten initiatives that we hope to move forward on with the support of plant biologists around the world (Agrawal et al., 2011). We can also refer to it as theGlobal Action Plan on Plant Proteomics in the 21st century (GAPs-21), and as the acronym symbolizes there is indeed a gap needing to be bridged between the plant proteomics researchers worldwide to engage in more cooperative research, breaking boundaries, and having an open-door policy to tackle the pressing need for translational proteomics, that is, from the lab to the field (Agrawal et al., 2012a,b). With this background, we discuss below some of the advancements seen recently, which have a relevance in shaping plant proteomics research tomorrow and tackling the issues that are being raised in this review, namely food security and safety.

\section{B. Technical Progression}

The proteome of a cell or tissue at a specific time point is extremely complex and diverse. Each current technique is only able to focus on a subfraction of proteins due to the complex chemical nature of proteins and their large dynamic range. Since no polymerase chain reaction (PCR) equivalent exists for multiplying proteins, each technique has a strong bias toward the most abundant proteins. The biggest challenge is to develop techniques to measure the deep proteome and to create a workflow to handle the data. It is currently impossible to study the whole proteome in one single experiment. Therefore, a proteomics experiment has to be designed very carefully according to the biological questions that have to be answered. An array of approaches has been developed to address proteome analysis. There are two main complementary approaches in proteomics: a gel-based approach (also known as protein-based approach) and a gel-free approach (also called peptide-based approach). 2-DGE coupled to spot picking and tandem mass spectrometry (MS/MS) is the cornerstone of proteome analysis and has an unequalled resolving power for separation of complex protein mixtures. It is a complete methodology providing a qualitative and quantitative high-resolution image of intact proteins giving a good overview of different isoforms and posttranslational modifications (PTMs). However, 2-DGE is difficult to automate and is greatly dependent on a scientist's skills and has a limited throughput. Most of the gel-free approaches are based on a bottom-up approach, where intact proteins are digested into peptides prior to separation. The physical and chemical properties of tryptic peptides are more homogeneous than 
protein extracts, which facilitates automated separation via multidimensional chromatography (MDLC).

\section{Protein Extraction}

Protein sample preparation is a critical step and is absolutely essential for obtaining good results. Most plant tissues are not a ready source and need specific precautions. When a particular group of proteins is of interest, a prefractionation technique needs to be applied. Various strategies have been developed over the years to fractionate proteins into subproteomes based on biochemical, biophysical, and cellular properties and are discussed (Ephritikhine, Ferro, \& Rolland, 2004; Rose et al., 2004; Righetti et al., 2006; Bodzon-Kulakowska et al., 2007; Barkla et al., 2009).

The majority of the plant protocols introduce a precipitation step to concentrate the proteins and to separate them from the interfering compounds. In the eighties, much effort was invested in the establishment of robust 2-DGE and sample preparation methods for plant tissue (Damerval et al., 1986; Granier, 1988; Meyer et al., 1988), but proteomics had at that time still many technical limitations and was not yet widely applied. Later on, people picked up those "old" techniques, compared, and optimized them (Saravanan \& Rose, 2004; Carpentier et al., 2005; Isaacson et al., 2006; Mechin, Damerval, \& Zivy, 2007). Protein extraction differs for a protein based approach and a peptide based approach and both methods are complementary. In the first dimension of 2-DGE, none of the denaturants should interfere with the intrinsic charge of proteins, which excludes strong detergents, such as SDS (sodium dodecyl sulfate). For the extraction of proteins for a gel-free-based approach detergents cannot be used unless they are removed before separation and MS analysis by, for example, the filter aided sample preparation method (Manza et al., 2005; Wisniewski et al., 2009; Vertommen et al., 2011b) or chemically broken down (e.g., acid-labile surfactants, ALSs) (Yu et al., 2003). Currently, several commercially ALSs are available among others: RapiGest (Waters, Milford, MA), PPS, (Protein Discovery, San Diego, CA), Protease MAX (Promega, Madison, WI). A disadvantage of cleavable detergents is the co-precipitation of hydrophobic proteins together with the degradation products. Therefore, a commercially available detergent (Invitrosol TM LC/MS Protein Solubilizer Kit, Invitrogen, Grand Island, NY) has been developed that elutes in three peaks that are well separated from the elution times of most peptides (Invitrogen).

\section{Protein Separation}

The most widely used 2-DGE protocol separates denatured proteins according to two independent properties: isoelectric point $(\mathrm{p} I)$ and molecular mass $\left(M_{\mathrm{r}}\right)$. In the original procedure the first dimension, isoelectric focusing, was executed in thin polyacrylamide gel rods inside glass tubes (O’Farrell, 1975). Bjellqvist et al. (1982) introduced IPG generated by buffering acrylamide derivatives containing carboxylic and tertiary amino groups (Immobilines). Now-a-days IPG-gradient gels or "strips" are 
commercially available and have numerous advantages. High resolutions can be obtained by using IPG strips with narrow $\mathrm{pH}$ ranges (e.g., $1 \mathrm{pH}$ unit) (Hoving, Voshol, \& Oostrum, 2000; Hoving et al., 2002).

A technical advancement in the second dimension is the development of the polyacrylamide gradient gels that are immobilized on a low-fluorescence plastic back. This ensures a maximum resolving capacity, gives robust strong gels that can be sent for automated spot picking and the low-fluorescence background enables the usage of fluorescent dyes. In the old days, gels were mostly run separately on a horizontal tray. Then vertical electrophoresis equipment was introduced where up to 12 gels can now be run simultaneously. Currently the horizontal electrophoresis is reintroduced. A new high-performance electrophoresis (HPE) system was recently developed whose separation in the second dimension is performed at higher voltages where up to four low-fluorescence plasticbacked flatbed gels can be run in parallel (Serva, Heidelberg, Germany). Becher et al. (2011) describe its testing in Bacillus subtilis.

Classical 2-DGE is not suitable to analyze native proteins, protein complexes, and hydrophobic proteins. For an overview on the alternatives on classical 2-DGE, the reader is referred to Miller, Eberini, and Gianazza (2010). For a recent overview on the techniques used to analyze hydrophobic proteins in plants, readers are referred to Vertommen et al. (2011b) and Kota and Goshe (2011).

\section{Peptide Separation}

Two-dimensional (2-D) LC-separation prior to MS analysis was introduced more than 10 years ago based on strong cation exchange (SCX) and reversed phase (RP) chromatography (Wolters, Washburn, \& Yates, 2001; Washburn et al., 2002). The separation of complex mixtures of tryptic peptides profited enormously from the development of commercially available capillary columns suitable for RP chromatography (Tomer et al., 1994; Carr, 2002). Also, the development of nanocolumns with smaller particles and higher pressure ultra-performance LC (UPLC) systems (Wilson et al., 2005) was a critical factor. Gilar et al. (2005) introduced an alternative system based on RP-RP where peptides are separated using two different $\mathrm{pH}$ values for elution from the first and second RP column. According to the authors, the advantages of this approach are: (i) after optimization, the number of peptides divided in several consecutive fractions is very limited; (ii) the peptide losses in the first dimension are smaller compared to SCX separation; and (iii) the mobile phases are salt free. A commercial hardware platform for 2-D RP-RP nano-UPLC (2-D nano Acquity) has been introduced by Waters, and has already been successfully used by Vertommen et al. (2011a) to analyze plasma membrane proteins. To take advantage of the properties of both gel-based protein and gel-free peptide separation, the two techniques can be used in a geLC approach. Proteins are first separated according to their molecular size through SDS-PAGE. After removal of the detergent and in-gel digestion of the proteins, the resulting peptides are separated using a RP column which can be on-line coupled to a mass spectrometer. Main advantages are that the 
strong solubilizing power of SDS is used for protein solubilization and that a semiautomatic workflow is achieved. The final peptide mixture present in one LC run is significantly reduced in complexity which makes the chance of identifying low abundant proteins higher. On the other hand, the method is less suitable for quantitative studies due to artifacts in electrophoresis and in-gel digestion.

\section{Gel-Based Protein Quantification}

One of the biggest advances in protein staining in terms of reproducibility and throughput was the development of succinimidyl ester derivatives of different cyanine fluorescent dyes that modify free amino groups of proteins prior to separation (Unlu, Morgan, \& Minden, 1997). Succinimidyl ester derivatives react with the nucleophilic primary amines, subsequently releasing the $N$-hydroxysuccinimide group. At a specific $\mathrm{pH}$ (8.5), these reagents react almost exclusively with the $e$-amino group of lysine to form stable amide linkages that are highly resistant to hydrolysis. Originally, only two different cyanine dyes were included ( $\mathrm{Cy}_{3}$ and $\mathrm{Cy5}$ ) but the concept was extended with a third dye (Cy2) that opened the way for a total new experimental design that further exploits the sample multiplexing capabilities of the dyes, by including an internal standard (Alban et al., 2002, 2003). The internal standard is a mixture of equal amounts of each sample and guarantees a high accuracy of protein quantification, reduces the variability considerably, and justifies the use of powerful parametric statistics after transformation of the standardized volume (Karp \& Lilley, 2005). For an overview on protein staining and quantification of proteins the reader is referred to (Miller, Crawford, \& Gianazza, 2006). It should be noted here that protein identification is usually done by MS.

\section{Mass Spectrometry-Based Protein Quantification}

Recent advances in plant proteomics have been largely made possible by developments in biological MS. The orbitrap mass analyzer has become the instrument of choice for many proteomics applications, since its commercial introduction in 2005 because of its ability to deliver low-ppm mass accuracy and extremely high resolution, all within a time scale compatible with nano-LC separations. One powerful and highly specific type of MS analysis is based on selective reaction monitoring (SRM), also called multiple reaction monitoring (MRM). Lehmann et al. (2008) called this approach Mass Western and used it to analyze the specific isoforms of sucrose phosphate synthase in Arabidopsis. In an SRM experiment, a predefined precursor ion and one of its fragments are selected by the two mass filters of a triple quadrupole instrument and monitored over time for precise quantification (Lange et al., 2008).

Most peptide-based quantitative proteomic analyses are comparative or relative and are based on universal approaches requiring chemical labeling of peptides and are suitable for plant protein/peptide labeling. Among others there are isobaric tag for relative and absolute quantitation (iTRAQ), isotopecoded affinity tag (ICAT), and 
labeling with $\mathrm{H}_{2}{ }^{18} \mathrm{O}$ while digesting the protein samples. In contrast to relative quantification, absolute quantification of peptides (AQUA) relies on the synthesis of isotopically labeled peptide standards, for example in SRM experiments. The need for synthesis of isotopically labeled peptides somewhat limits the scale for quantitative analysis. These techniques and their applications to quantitative plant proteomics methods are reviewed in Oeljeklaus, Meyer, and Warscheid (2009), Kline and Sussman (2010), Schulze and Usadel (2010), and Bindschedler and Cramer (2011a,b). However, an increasing number of experiments are now being attempted using label-free approaches for plant proteome research (America \& Cordewener, 2008; Griffin et al., 2010; Matros et al., 2011). For an overview of the latest developments on peptide-based separation and label-free quantification the reader is referred to Matros et al. (2011).

Alternatives to chemical labeling and label-free quantitation are the use of metabolic labeling. While stable isotope labeling with amino acids in cell culture (SILAC) is highly successful in animal systems, it is less applicable to plant cell cultures as amino acid incorporation is poor and labeling is only partial, due to the ability of green cells to fix carbon. However, plant-specific quantitative methods such as HILEP and SILIP (Palmblad, Bindschedler, \& Cramer, 2007; Bindschedler, Palmblad, \& Cramer, 2008; Schaff et al., 2008; Kline, Barrett-Wilt, \& Sussman, 2010; Bindschedler \& Cramer, 2011a,b) take full advantage of plant metabolism and long-established culture practices. In such approaches, whole plants are grown and proteins are labeled in hydroponic or plant cell cultures with ${ }^{15} \mathrm{~N}$ inorganic salts as sole nitrogen source as reviewed in Bindschedler and Cramer (2011b) and Arsova, Kierszniowska, and Schulze (2012). Apart from nearly complete, convenient, and cost-effective labeling of Arabidopsis with $15 \mathrm{~N}$ salts, it was shown that other plants such as tomato (Schaff et al., 2008) and the woodland strawberry Fragaria vesca (Bindschedler, Dunwell, Jambagi, \& Cramer, unpublished data) can be labeled this way. For instance, Figure 2 shows that $F$. vesca grown hydroponically was amenable to quantitative proteomic analysis using isotopically different nitrogen salts in the growth medium. F. vesca leaves from ${ }^{14} \mathrm{~N}$ and $15 \mathrm{~N}$ grown plants were pooled in a $1: 1$ ratio. Proteins were extracted, digested, and analyzed by nLC-ESI-MS/MS. Quantitation was then performed by comparing the peak area ratios of the ${ }^{14} \mathrm{~N}$ and $15 \mathrm{~N}$ isotopic envelopes of the corresponding co-eluting ${ }^{14} \mathrm{~N}$ and ${ }^{15} \mathrm{~N}$ peptide doublets.

\section{Posttranslational Modifications Analysis}

Posttranslational modifications (PTMs) are covalent processing events that determine a protein's activity state, localization, turnover, and interaction with other proteins (Mann \& Jensen, 2003). Despite the pivotal roles of PTMs in cellular functions, the studies on PTMs are cumbersome. PTMs can be analyzed at both the protein level and the peptide level. Once modified proteins have been identified, PTMs of the proteins are subsequently characterized by MS (Jensen, 2004). Developments in affinity based 
enrichment and MS should bring new insights on the dynamics and spatio-temporal control of protein activities by PTMs, and reveal their roles in biological processes (Jensen, 2004). Mass spectrometers continue to evolve towards increased sensitivity, higher mass accuracy and resolving power, improved duty cycle, and more efficient fragmentation of peptides in MS/MS. However, mapping PTM is a quite challenging task due to low abundance and changed physico-chemical characteristics of the modified peptides.

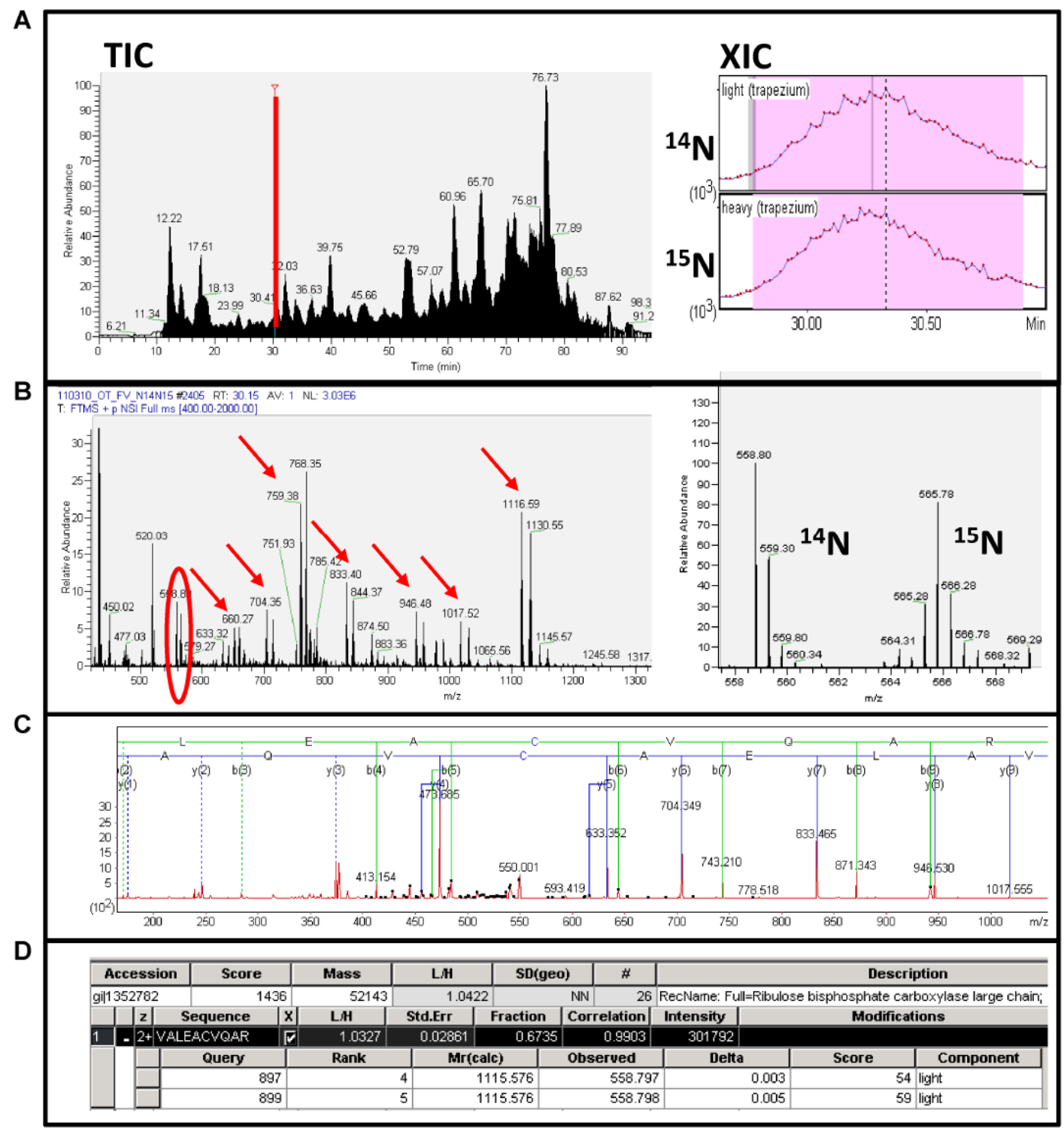

FIGURE 2. Metabolic ${ }^{15} \mathrm{~N}$-labeling is suitable for relative quantitation of proteomes of Fragaria vesca (wild strawberry) as shown for the doubly charged peptide VALEACVQAR. A ratio of 1 is expected as equivalent amounts of ${ }^{14} \mathrm{~N}$ grown leaves were pooled with ${ }^{15} \mathrm{~N}$ grown leaves. A: Total and extracted ion chromatograms of an nLC-ESI MS analysis. ${ }^{14} \mathrm{~N}$ and ${ }^{15} \mathrm{~N}$ extracted ion chromatograms show co-elution of the ${ }^{14} \mathrm{~N}$ and ${ }^{15} \mathrm{~N}$ peptide isotopologues. B: MS spectrum at $30.03 \mathrm{~min}$ with details of the ${ }^{14} \mathrm{~N}$ and ${ }^{15} \mathrm{~N}$ doubly charged isopotologues of VALEACVQAR show a ${ }^{14} \mathrm{~N} /{ }^{15} \mathrm{~N}$ ratio close to 1 . C: MS/MS spectrum of the ${ }^{14} \mathrm{~N}$ isopotologues. D: Identification and quantitation details for the doubly charged peptide VALEACVQAR. XCalibur (ThermoFisher Scientific, Hemel, Hempstead, UK) and Mascot Distiller (MatrixScience, London, UK) softwares were used for data presentation and analysis as described previously (Bindschedler \& Cramer, 2011b). 
The lability in the gas phase of many modifications, which are easily lost under vibrational (collisional or infrared) excitation without revealing their positions, lowers their detection efficiency. The alternative non-vibrational excitation technique electron capture dissociation (ECD) has shown on several occasions its profound potential for PTM characterization (Kjeldsen et al., 2003). With ECD, the positions of phosphorylation, $\mathrm{N}$ and $O$-glycosylation, sulfation, and g-carboxylation can be easily established; these modifications are rapidly lost upon vibrational excitation. In this approach, termed "reconstructed molecular mass analysis" (REMMA), the molecular mass distribution of the intact protein is measured first, which reveals the extent and heterogeneity of modifications. Then the protein is digested with one or several enzymes, with peptides separated by reversed-phase HPLC, and analyzed by Fourier transform MS (FTMS) (Kjeldsen et al., 2003). When a measured peptide molecular mass indicates the possibility of a PTM, vibrational excitation is applied to determine via characteristic losses the type and eventually the structure of the modification, while ECD determines the PTM site. ECD enables efficient sequencing of phosphopeptides, glycopeptides, and other types of modified peptides.

Bond, Row, and Dudley (2011) describe the protocols for mapping plant PTMs. Among the studied PTMs are phosphorylation, glycosylation, ubiquitination, methylation, acetylation, sulfonation, sumoylation, myristoylation, palmitoylation, prenylation/farnesylation, and the redox proteome. $N$-terminal myristoylation plays a vital role in membrane targeting and signal transduction in plant responses to environmental stress. Podell and Gribskov (2004) developed a new method based on a plant-specific training set and the use of a probability-based hidden Markov model for predicting $N$-terminal myristoylation sites specifically in plants. PhosPhat, $\mathrm{P}^{3} \mathrm{DB}$, PlantsP, and plantsUPS are plant-specific databases useful to investigate PTM. PhosPhat is the Arabidopsis Protein Phosphorylation Site Database developed by Heazlewood et al. (2008). Moreover, Gao et al. (2009) developed a plant-specific protein phosphorylation Database P3DB. PlantsP is a server developed by the Purdue University Database Group and offers several tools among them the prediction of phosphorylation and meristoylation sites. The most extensively studied PTM is phosphorylation (Kersten et al., 2006; Kersten et al., 2009; Schulze, 2010; Bond, Row, \& Dudley, 2011). There are a variety of techniques and methodologies for phosphoprotein analysis (radioactive labeling, immunoprecipitation, affinity chromatography, and chemical derivatization). Advancement in analytical techniques and evolution of various high-resolution mass spectrometers during the last decade has accelerated the large scale screening of PTMs from various biological sources.

\section{Proteogenomics and Genomic/Proteomic Databases}

Facilitated by the speed and decreased cost of third-generation DNA sequencing, genome-wide sequencing of plant species, in particular main food crops, is on the rise after a decade of sequencing of A. thaliana, and the Indica and Japonica rice subspecies. In 2005, the first map-based sequence of the annotated rice genome was also 
completed (International Rice Genome Sequencing Project, 2005). Entire genomes are now becoming available for some of the major crops, such as maize (Schnable et al., 2009), sorghum (Paterson et al., 2009), potato ( $\mathrm{Xu}$ et al., 2011), tomato, soybean, domesticated apple (Velasco et al., 2010), or banana (D'Hont et al., 2012), as recently reviewed in (Feuillet et al., 2010; Miller, Eberinin, \& Gianazza, 2010; Sonah et al., 2011) and at http://en.wikipedia.org/wiki/ List_of_sequenced_eukaryotic_genomes\#cite_note-42. With the explosion in the amount of available data, it is increasingly difficult to provide a complete and updated picture of genome availability. Thus, this review has to restrict itself to the main model and crop species and some basic aspects of their genomic and proteomic sequence acquisition and availability.

In general, genome sequence assembly and annotation of crops are challenging tasks due to large genome sizes and the fact that typically over $80 \%$ of the genome is constituted by repetitive transposable elements, as it is the case for the 2.3 billion bases large maize genome (Schnable et al., 2009), barley, and wheat. Polyploidy is another challenge to overcome for many cultivated crops, for example, wheat, potato, tomato, oil seed rape Brassica napus, and even fruit crops (such as banana or strawberry), thus requiring independent sequencing of the various wild-type haplotypes (Shulaev et al., 2011).

Genome annotation, which will give information on gene function predominantly, relies on the prediction of protein-encoding genes based on sequence comparison or in silico gene prediction. However, validation of open reading frames (ORFs) prediction depends on extensive transcriptomics sequence data, such as the recently published ten thousands of unique cDNAs that were sequenced and assembled for barley (Matsumoto et al., 2011) and maize (Soderlund et al., 2009). Alternatively or in combination, a proteogenomics approach using large-scale shotgun proteomics has proven to be extremely powerful in discovering unpredicted ORFs of extensively and intensively annotated genomes of model organisms, such as fly, human, and Arabidopsis (Castellana et al., 2008; Castellana \& Bafna, 2010). For Arabidopsis, this is illustrated by $13 \%$ new ORFs that were identified in an indepth proteo(geno)mics study (Castellana et al., 2008).

Improved MS-based proteomic workflows now allow proteogenomics to become the method of choice to validate exon-intron structures of ORFs by mapping the identified peptides to the genome and grouping these peptides into proteins (Ansong et al., 2008; Armengaud, 2010). Such approach has already been described extensively not only for Arabidopsis (Castellana et al., 2008) but also for rice (Helmy, Tomita, \& Ishihama, 2011), and fungal wheat and barley pathogens (Bringans et al., 2009; Bindschedler et al., 2011). Proteogenomics can use imperfect genomic databases to identify proteins by proteomic means (Ansong et al., 2008; Castellana et al., 2010; Agrawal et al., 2011; Bindschedler et al., 2011) and help to annotate short or speciesspecific ORFs. Therefore, newly assembled and (poorly) annotated crop genomes still 
enable proteomic investigations. This is quite important as in protein sequence databases, such as UniProtKB the plant protein entries are well behind the entries for species of other kingdoms. For instance, the number of UniProtKB entries for Viridiplantae is underrepresented with only 32,666 entries out of 536,789 total entries, representing less than $10 \%$ of total protein entries $\mathrm{ram} /$ plants/statistics - accessed in July 2012). Of these plant protein entries, one third consists of Arabidopsis entries $(10,617)$ and over 2,000 entries from rice.

Concomitant with the emerging plant genomic and proteomic information (Armengaud, 2010; Renuse, Chaerkady, \& Pandey, 2011), new bioinformatic tools are being developed to automatically map identified peptides on whole genomes (Sanders et al., 2011; Specht et al., 2011) and assign function to unknown proteins (Bindschedler et al., 2011). Such technological developments will make proteogenomic approaches even more popular and suitable for plant proteomics and complement quantitative plant proteomic measurements (Bindschedler \& Cramer, 2011a) by providing the necessary data on protein identity and function for the investigation of plant proteomes.

Resources for crop proteomics such as genomic and proteomic databases are still in their infancy. Most resources, with the exception of some maize and rice databases (Tables 1 and 2), have been developed for the model plant system Arabidopsis as reviewed by Weckwerth et al. (2008).

\section{Preparing the Stage for Systems Biology: Data Integration atSystems Level}

Messenger RNA (mRNA)-based approaches are extremely powerful and highly automated, allowing massive screening of several genes at once. However, it is important to recognize that there might be a possible discrepancy between the messenger (transcript) and its final effector (mature protein). As most biological functions in a cell are executed by proteins and metabolites rather than by mRNA, transcript profiling does not always provide pertinent information for the description of a biological system. Expression studies on prokaryotic as well as lower and higher eukaryotic organisms revealed in certain cases a poor correlation between mRNA transcript level and protein abundance (Gygi et al., 1999; Griffin et al., 2002; Corbin et al., 2003; Greenbaum et al., 2003; MacKay et al., 2004; Tian et al., 2004; Carpentier et al., 2008b) or enzyme activity (Gibon et al., 2004). If transcripts are only an intermediate on the way to produce functional proteins and in turn proteins regulate the metabolite abundances, why measure mRNA? It is clear that a correlation between mRNA and protein abundance exists, and that several studies did find a correlation between mRNA (Goossens et al., 2003; Hirai et al., 2004) and metabolites, and in the cell all networks are connected. 
TABLE 1. A non-exhaustive list of some genomic and proteomic databases and websites for food crops

\begin{tabular}{|c|c|c|}
\hline Organism & Websites & Notes \\
\hline General database & http://www.plantgdb.org/ & Resource for comparative plant genomics \\
\hline \multirow{2}{*}{$\begin{array}{l}\text { Rice (Goff et al., } \\
\text { 2002; Yu et al., } \\
\text { 2002) }\end{array}$} & http://www.plantgdb.org/OsGDB/ & \multirow{2}{*}{ Genomes published in 2002} \\
\hline & http://rice.plantbiology.msu.edu/ & \\
\hline Wheat & http://www.wheatgenome.org/ & Sequencing in progress \\
\hline \multirow{5}{*}{$\begin{array}{c}\text { Barley (Mayer et al., } \\
\text { 2011) }\end{array}$} & http://www.public.iastate.edu/ imagefpcl & International Barley Sequencing Consortium (IBSC) \\
\hline & IBSC\%20Webpage/IBSC\%20Template-home.html & \\
\hline & http://www.shigen.niq.ac.jp/barlev/ & Sequencing in progress \\
\hline & http://150.46.168.145/gbrowse new/index.html & $\begin{array}{c}\text { Several sites with genome, cDNAs and ESTs databases } \\
\text { available }\end{array}$ \\
\hline & http://harvest.ucr.edu/ (cDNAs) & \\
\hline $\begin{array}{c}\text { Maize (Schnable et } \\
\text { al., 2009) }\end{array}$ & http://www.plantgdb.org/ZmGDB/ & Genome published in 2011 \\
\hline \multirow{2}{*}{$\begin{array}{l}\text { Sorghum (Paterson } \\
\text { et al., 2009) }\end{array}$} & http://www. plantgdb.org/SbGDB/ & \multirow[b]{2}{*}{ Genome published in 2009} \\
\hline & http://mips.helmholtz-muenchen.de/plant/sorghum/ & \\
\hline $\begin{array}{c}\text { Potato (Xu et al., } \\
\text { 2011) }\end{array}$ & http://solanaceae.plantbiology.msu.edu & Genome published in 2011 \\
\hline $\begin{array}{c}\text { Tomato and other } \\
\text { solanaceae }\end{array}$ & http://solgenomics.net/ & Genome draft unpublished \\
\hline \multirow{2}{*}{ Soybean } & http://soybeangenome.siu.edu/ & \multirow{2}{*}{ Genome published in 2010} \\
\hline & http://www.phytozome.net/soybean & \\
\hline Cucumber & $\begin{array}{c}\text { http://www.icugi.org/cgi- } \\
\text { bin/lCuGl/misc/PAG/cucumber_genome.cgi }\end{array}$ & \\
\hline Papaya & http://asgpb.mhpcc.hawaii.edu/papaya/ & \\
\hline Banana & http://www.musagenomics.org/ & Genome published in 2012 \\
\hline $\begin{array}{c}\text { Apple (Velasco et } \\
\text { al., 2010) }\end{array}$ & http://www.rosaceae.org/projects/apple_genome & Genome published in 2010 \\
\hline $\begin{array}{c}\text { Strawberry } \\
\text { (Shulaev et al., } \\
\text { 2011) }\end{array}$ & http://www.rosaceae.org/projects/strawberry_genome & Genome published in 2011 \\
\hline
\end{tabular}

\begin{tabular}{|c|c|c|}
\hline Organism & (2) & Notes \\
\hline \multirow{4}{*}{ General databases } & http://www.ebi.ac.uk & \multirow{2}{*}{ Includes SwissProt } \\
\hline & $\underline{\mathrm{html}}$ & \\
\hline & http://promex.pph.univie.ac.at/promex/ & Arabidopsis thaliana, Chlamydomonas reinhardtii, Medicago truncatula \\
\hline & & Potato, tomato, and other plants with MS data. \\
\hline \multirow{3}{*}{ Arabidopsis } & http://www.suba.bcs.uwa.edu.au & Sub-cellular localization \\
\hline & http://phosphat.mpimp-golm.mpg.de & Phosphorylation sites \\
\hline & http://www.ebi.ac.uk/intact/main.xhtml & Protein-protein interaction \\
\hline $\begin{array}{l}\text { Arabidopsis and maize } \\
\text { (Sun et al., 2009) }\end{array}$ & http://ppdb.tc.comell.edu/ & $\begin{array}{l}\text { Arabidopsis and maize-specific database, including PTMs and cellular } \\
\text { localization }\end{array}$ \\
\hline \multirow{2}{*}{$\begin{array}{l}\text { Rice (Helmy, Tomita, \& } \\
\text { Ishihama, 2011) }\end{array}$} & http://gene64.dna.affrc.go.jp/RPD/ & 2D-gel database \\
\hline & http://orvzapg.jab.keio.ac.jp/ & Protein database generated from a proteogenomic approach \\
\hline
\end{tabular}

Furthermore, each approach has its bias and drawbacks. Hence, several biological variables coming from transcripts, proteins, and metabolites need to be integrated to understand systems biology and will lead to new insights. Saito, Hirai, and YonekuraSakakibara (2008) review the strategy of combining transcriptome and metabolome studies as a powerful tool for helping the annotation of plant genomes. But data integration from different biological variables to understand the dynamic phenotype of a plant are even more challenging: (i) good algorithms and statistics are needed to extract significant information and to cope with the high dimensionality structure of 
the data, (ii) the data have to be of good quality, and (iii) the experimental set-up with the plants should not be too complicated. Wienkoop et al. (2008) present an approach to investigate the combined covariance structure of metabolite and protein dynamics in a systemic response to abiotic temperature stress in Arabidopsis wild-type plants. The concept of high-dimensional data profiling and subsequent multivariate statistics for dimensionality reduction, and covariance structure analysis is a powerful strategy to the systems biology of a plant under particular conditions. The systematic integration of transcript, protein, and metabolite profiling needs to be modeled in time to find the correlations between the different levels and this is a challenge for bioinformaticians and statisticians (Weckwerth, 2011).

\section{Global food security and safety: challenging our survival}

"Civilization as it is known today could not have evolved, nor can it survive, without an adequate food supply.”- Dr. Norman Ernest Borlaug (A Nobel Laureate)

Food security is defined as a situation in which all people at all times have physical and economic access to sufficient, safe, and nutritious food to meet their dietary needs and live an active healthy life (World Food Summit, 1996). Over the past couple of decades, food security and its related issues have been one of the most discussed topics around the world, and will likely remain a prime concern for the next 50 years and beyond. There are many issues/factors that affect global food security, including global population, climate change, and exploitive agriculture (Fig. 3). Despite global efforts in this direction, the number of hungry or under-nourished people has increased by 75 million throughout the world in the year 2007 alone, and the report of the US Department of Agriculture has predicted that the number will rise sharply to 1.2 billion by 2017 (FAO, 2010).

Improvement of crop and horticultural plants has long been the major focus for addressing and solving food security related issues. The "green revolution" during the 1960 s to 1970 s is burning evidence; where higher wheat production has saved almost 10 billion people suffering from severe hunger worldwide (Hesser, 2006). This first revolution was also "recognition" for the first global and united effort for a single aim called "food security." Thanks to the work of among others, Dr. Norman Ernest Bourlaug introduced some important traits in wheat crop like disease resistance and dwarf height through breeding techniques. Combined with proper irrigation and fertilization, it was shown to the world that wheat yield could be doubled in Mexico, USA, and major South-Asian countries (like India, Pakistan, and Bangladesh) (Hesser, 2006). In a recent commentary published in the journal "Nature," Dr. Jason Clay had elegantly pointed to some of the needed approaches for global farming (Clay, 2011), which if taken together might enable the present agriculture to perform in a more sustainable way (Herdt, 2006).

Fighting against the global food security issues in the after days of "green revolution," scientists were convinced that conventional technologies alone will not be able to feed the 
world of tomorrow. Thus, the search for modern technologies [e.g., plant biotechnology, especially crop biotechnology (Herdt, 2006)] took a protagonist place. Crop biotechnology has been of great importance in improving the global agricultural production and reducing the environmental impact associated with the use of pesticide and with soil erosion, in both developed and developing countries (Barfoot \& Brookes, 2007; Brookes \& Barfoot, 2009). In developing countries alone, the biotech crops have proven beneficial to more than 12 million farmers (James, 2009). Plant breeders have also used the technology to improve the nutritional value of crops (NewellMcGloughlin, 2008). However, there is awareness that, not only crop improvements but a thorough postharvest management system and smart food processing technologies are necessary to guarantee availability of food in coming years.

\section{Global Crisis of Food Security, Safety, and Human Health}

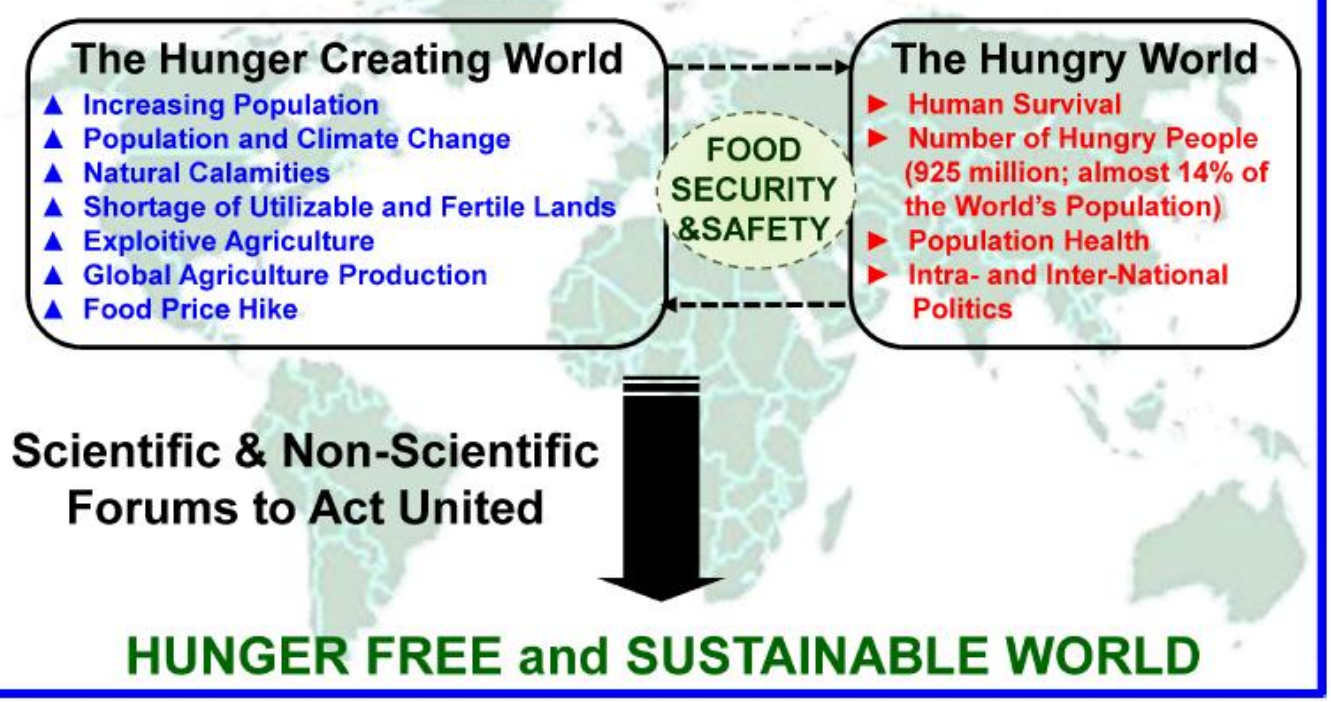

FIGURE 3. The vicious cycle of the global food security crisis. Food security is a multifaceted problem, which is affected by and affects multiple factors worldwide. We show here the major issues that are the cause of food crisis, as well as those created by the food crisis. These problems are both social and scientific in nature, and therefore, we need to come together and act united toward a hunger free and sustainable world.

Food analysis and safety are growing issues that have received attention in recent years. Over the past few years, regulatory agencies have introduced and defined the term - food contamination (Council Regulation 315/93, 1993). Moreover, agencies have recommended the use of appropriate analytical tools to properly identify and quantify the very low levels of food contaminants. One such tool is "proteomics," and as the section below highlights, we discuss the translation of discoveries and advancements in plant proteomics and MS to solving global issues of food security and safety by discussing some examples from model to non-model plants, crops, biofuels, biotic and abiotic stresses, postharvest technology, foodstuff analysis, genetically modified crops and allergens. 


\section{Translating plant proteomics knowledge towards food security and safety issues}

Food security, analysis, safety, and human health include multiple research areas across various disciplines from crop improvement to postharvest technologies. In this section, we provide some recent examples and progress where proteomics and the use of MS are playing important roles in addressing these issues.

\section{A. Model Versus Non-Model Plants}

In past decades, research communities have focused on species that facilitate experimental laboratory research because of their particular size, generation time, and undemanding growth requirements that make it amenable to high-throughput analysis (e.g., Escherichia coli, Saccharomyces cerevisiae, Caenorhabditis elegans, Drosophila melanogaster, and Mus musculus). The first classical plant model, A. thaliana, is ideal for laboratory studies. However, Arabidopsis is phylogenetically only related to a limited number of agricultural important species, which restricts the extrapolation of results to other species (translational proteomics; see also Agrawal et al., 2012a). Brachypodium is a relative to a large number of temperate cereal crops and grasses and has emerged with its small nuclear genome, a life cycle of less than 4 months and its small size as a new interesting model plant (Draper et al., 2001). Arabidopsis research has provided an enormous quantity of data used in genomics, transcriptomics, proteomics, and metabolomics. Brachypodium starts to be integrated in proteomics studies (Larré et al., 2010; Wang et al., 2010). However, the plant kingdom has an enormous richness in biodiversity providing a wealth of possibilities to interest specific needs of nutritionists, breeders, plant physiologists, agricultural researchers, and food scientists. Research on models has proven in the past to be of great value for fundamental research but models need to be validated and some models are simply too far away from their application.

In the past decade, with the rapid development of sequencing techniques and the rapid drop in price, the number of genome-sequencing projects increased and more and more plants and specifically crops are getting sequenced and put forward as "representatives." Nowa-days, several "representatives" have seen their genome fully sequenced (Feuillet et al., 2010) (find latest data on http://www.plantgdb.org/), one should also take into account the fact that the genome of those "economically important representatives" might not be annotated and that the genomes are quite complex often because of the size and the ploidy level. Genome duplication, polyploidy, and allopolyploidy have played an important role in the evolution of plants including important crops (Soltis \& Soltis, 1999). This increase in genetic diversity enables plants to diverge and specialize and to survive stress conditions. However, its occurrence considerably complicates the analysis of real crops (Carpentier et al., 2011). Proteomics approach has a great potential to study non-model species (Carpentier et al., 2008a,b, 2011; Vertommen et al., 2011a). Proteins are well conserved making the high throughput identification of non-model gene products by comparison to well-known orthologous proteins quite efficient (cross-species identification) (Liska \& Shevchenko, 2003). While some of the 
studies done in "the classical model" plants relied totally on the genome sequences to obtain identification only based on peptide mass fingerprints (PMF), the largest part of the studies are nowadays done using MS/MS to improve the confidence one can put on protein identification and reduce the occurrence of false identification. Regarding this last aspect, cross-species identification is therefore an important issue and an extremely useful tool to study "orphan" species, whose genome is not yet sequenced, or when only a few expressed sequence tag (EST) sequences are available. Numerous reviews have recently been published on the subject by Bräutigam et al. (2008), Carpentier et al. (2008a), Remmerie et al. (2011), or Vertommen et al. (2011a,b). Indeed, although when considering only the identification of proteins from orphan species, two main strategies have been followed in the past: either using protein homology or using de novo sequencing (Remmerie et al., 2011). In the first case, databases of proteins or ESTs closely related to the considered species (e.g., same species, same family, or same taxonomical group) are created and used with search engines. In the second one, the bioinformatics tool used is rather a databasefree search that is performed. The two approaches can also be combined (i.e., as provided by Shevchenko et al., 2001; MSBLAST: http://dove.embl.de/Blast2/ msblast.html). However, it should be mentioned that combinations of both approaches can be used. The studies purely based on de novo sequencing have become very rare in the last 5 years. Furthermore, alternative approaches are used. Given the relatively high protein sequence homology between even very distant plants instead of using sequences of close relatives, databases containing as much as possible information are often used. However, this approach is at the cost of computation time.

\section{B. The Application of Proteomics and Mass Spectrometric Tools in the Study of Biofuel Crops}

In recent years, public concern over the rising environmental and financial costs associated with the consumption of fossil fuels, has led to an intensified search for cleaner and more sustainable energy sources. Biofuels constitute one such alternative that has attracted significant global interest. From 2000 to 2009, global bioethanol production increased from 16.9 to 72.0 billion liters, while biodiesel output surged from a low level of 0.8 to 14.7 billion liters (Sorda, Banse, \& Kemfert, 2010). These impressive gains have had the welcome corollary effect of generating new economic opportunities in the rural sector, whilst promoting energy security and selfsufficiency in a more environmentally sustainable way. In spite of these advantages however, the growth of the biofuels industry, which has essentially relied on food crops (such as cereals, oily seeds, and sugarcane/sugarbeet) as feedstock, has also been blamed for rising food prices and instability in the food supply market. To reduce the negative impact that biofuel production may have on food security issues, greater emphasis is now being focused on the development of second-generation bioethanol and biodiesel. Here, some of the latest developments in biofuels research will be presented, with a special focus on the contributions made by proteomics and MS. Attention will not only be drawn to important biofuel crops, such as Sorghum and Jatropha. But an attempt has been made to cover how proteomics and MS techniques 
are being applied more broadly to the field of second-generation biofuel research with the goal of improving the efficiency of the biomass-to-biofuel production process. As shown here below, proteomics and MS technologies are continuing to make a vital contribution to the successful development of a sustainable global biofuels industry.

To start we shall first consider the latest work done on Sorghum bicolor. The controversy surrounding the use of maize and other food crops for biofuels production brought attention towards an African grain plant called sorghum. In addition to its importance as a source of food, Sorghum (particularly sweet stem varieties) has attracted significant interest in recent years as a promising energy crop (Munns \& Tester, 2008). Sorghum can grow in a wide range of marginally arable geographical areas as it requires relatively less fertilizer and water compared to other grain crops (Kasuga et al., 1999). The combination of $S$. bicolor natural drought tolerance traits and its recent genome sequencing milestone (Paterson et al., 2009) makes it one of the most logical model plant for both proteomics and genomics research in cereals. Sorghum proteome analysis profiled the 2-DGE protein patterns of the total soluble proteins and secreted culture filtrate protein, and culminated in a comprehensive mapping and characterization of the sorghum cell suspension culture secretome (Ngara \& Ndimba, 2011). More recently, this group completed the study towards profiling and identification of sorghum seedling's salt-stress responsive proteins (Ngara et al., 2012).

Another important biofuel crop species that has been studied using proteomics is Jatropha curcas, a non-edible oilseed crop. Similar to Sorghum, Jatropha is a hardy plant that can withstand arid and semi-arid conditions (Sudhakar Johnson, Eswaran, \& Sujatha, 2011). Proteomics has mainly been applied to Jatropha to foster a better understanding of the factors involved in maintaining its high seed oil content. In a study conducted by Popluechai et al. (2011), a comprehensive characterization of the proteome of Jatropha seed oil bodies was achieved using LC-MS/MS, revealing the major contribution of three main types of oleosins.

In terms of second-generation biofuels, the difficulties and high costs involved in the breakdown of lignocellulosic materials into easily fermentable sugars, is the main stumbling block that is preventing the widespread uptake of this form of biofuel production. Researchers in the field however are making important progress by beginning to narrow in on the natural process of biomass degradation, as accomplished by specialist microorganisms. In a study by Tolonen et al. (2011), quantitative MS analysis of both the proteome and secretome of Clostridium phytofermentans, allowed for a systems-wide analysis of the various proteins implicated in the efficient fermentation of cellulosic biomass. As a result of this study, over 2,500 proteins were identified, which will serve to direct the scientific identification and engineering of targets for second-generation biofuel production. In a similar vein, the comprehensive analysis of the secretome of the fungus Phanerochaete chrysosporium, using iTRAQ LC-MS/MS, allowed researchers to 
quantitatively profile the expression of over 300 proteins involved the degradation of several types of agricultural and forestry wastes (Adav, Ravindran, \& Sze, 2012). This marked an improvement of up to sevenfold compared to previous studies and will provide important clues as to how enzymatic cocktails can be optimized for improved biofuel production.

\section{Crop Disease Proteomics: Reducing Pathogen Damage to Agricultural Crops}

An estimated $10 \%$ of the developed world's food is lost due to plant pathogens annually (Strange \& Scott, 2005), and much more during epidemics. The greatest losses suffered by agricultural crops today are caused by insect damage and plant diseases, with plant diseases being the most devastating. Serious plant diseases are caused by bacteria, viruses, nematodes, as well as fungi and fungus-like Protozoa, but fungi probably cause the most severe losses around the world because there are more genetically diverse plant pathogenic fungi than there are plant pathogenic bacteria or viruses. Clearly, molecular plant pathology is an area in which a scientific approach to enhancement of disease resistance can make a significant impact on crop productivity. Many of the benefits of this research would eventually reach the developing world, where agricultural losses to pathogens tend to be higher. Losses also occur where pathogens contaminate grain or other edible produce with mycotoxins. The cost of deoxynivalenol contamination of wheat alone by Fusarium graminearum has cost the US and Canada an estimated \$3 billion since 1990 (Ward et al., 2008); in Southern Africa, where subsistence farmers are often forced to consume contaminated grain, the cost in human suffering must also be considered (Ncube et al., 2011). The best strategy for controlling plant diseases includes using resistant crop cultivars, and for plant breeders to develop these, an understanding of plant-pathogen interactions is essential. Since proteins are important players in plant-pathogen communication, proteomics is a logical choice for dissecting the molecular events that frequently lead to plant disease.

A great deal of progress has been made in model plant- pathogen systems, notably with Arabidopsis and bacterial elicitors, and this has advanced the understanding of events at the molecular level which lead either to disease progression or limited pathogen growth in the case of disease resistance (Nishimura \& Dangl, 2010). Thus, the gene-for-gene theory, advanced by Flor (1971), based on the interaction between plant resistance $R$-genes and pathogen avirulence avr-genes in flax-flax rust, has been confirmed using a proteomics approach (Dodds et al., 2006) and has evolved into the zigzag model described by Jones and Dangl (2006). This model seeks to explain molecular events that occur upon infection of a plant by a pathogen and although it was built up with experimental evidence from $A$. thaliana, it is generally applicable to other plant-pathogen systems. In brief, the plant must overcome or neutralize the actions of various pathogen elicitors, which it first recognizes as microbe-associated molecular patterns (MAMPs). If the pathogen is successful, expression of avirulence proteins results and these interact with plant $R$-gene products 
the majority of which are nucleotide-binding site leucine-rich repeat (NBS-LRR) proteins (Boller \& Felix, 2009). On the other hand, if the plant is able to overcome the action of the avr proteins, a hypersensitive response results. This causes a halt to the invading pathogen with little penalty to the host. If it cannot, then the pathogen completes its life cycle and causes disease. A real-life example of this interaction is presently playing out in East Africa where the wheat $R$ gene $S r_{31}$, the main line of defense used by breeders to combat stem rust caused by Puccinia graminis, has been overcome by isolate Ug99 with devastating results for the region (Singh et al., 2008). The impact of Ug99 in the Western hemisphere would be less, as P. graminis can be well managed by fungicides. The tools available for crop proteomics cannot be compared to those available for Arabidopsis research. For example, with the exception of rice, no major crop plant has a fully sequenced (i.e., mature and nicely annotated) genome; in many cases creation of genetic mutants-for example, through the use of transgenics-is difficult; only a few $R$ genes have been cloned and characterized, and far fewer avr genes.

The contribution from the studies that employed model plant-pathogen systems and MS-based proteomic techniques are comparable with other conventional approaches that successfully characterized plant-pathogen interaction to date. Expression profiling at the protein level represents the core of current proteomic approaches. However, the majority of comparative proteomics studies detected and identified only a handful of responding proteins (Rampitsch \& Bykova, 2012). The most successful studies that identified dozens and even hundreds of proteins involve subcellular fractionation and LC separation in addition to the gel electrophoresis approaches. These studies reported that many plant proteins were differentially expressed upon pathogen attack or elicitor challenge but only a few responding proteins were identified on the pathogen side. One of the reasons for difficulties in studying the protein expression of the invading pathogen is the lack of established methodologies for recovery of pathogens and/or enrichment of proteins from the pathogens postinfection. Another important observation is that the transcript (mRNA) levels of some genes did not correlate with the protein expression pattern, and some proteins were found to be regulated at the translational and posttranslational level. Based on proteomics derived informations, our current understanding of biological processes occurring during plant-pathogen interaction remains rudimental. More in-depth analysis involving spatial and temporal distribution of responding proteins and metabolites will help elucidate the details of pathogens invasion strategies and the complex interplay between pathogen and host. Although many proteins were found to be differentially expressed either in the plant or pathogen postinfection, roles of individual proteins and mechanisms involved in a particular disease have to be validated by further experiments.

In spite of these challenges, good progress has been made in a number of croppathogen systems (Quirino et al., 2010). Most preliminary studies, especially with poorly characterized interactions employ 2-DGE coupled with MS/MS and 
homology-based matching. These studies tend to report increased expression of antioxidant enzymes, fungal cell-wall degrading enzymes, pathogenesis related (PR) proteins, and certain metabolic enzymes (i.e., glyceraldehyde-3-phosphate dehydrogenase). There are many examples of such published studies, for example barley-F. graminearum (Yang et al., 2010), pea-downy mildew (Peronosporaviciae) (Amey et al., 2008), and rape-seed-blackleg (Leptoshaeria maculans) (Sharma et al., 2008). Although this indicates that diverse plant pathogen systems share common response pathways, it highlights some of the limitations of the 2-DGE approach when applied to whole, unenriched tissues. More recently, gelfree techniques such as quantitative MDLC have been applied. For example, Marsh et al. (2010) used iTRAQ to compare the response of susceptible $V$. vinifera (grape) to powdery mildew caused by Erysiphe necator. Their results indicated that the plant was able to mount a basal defense response, but could not overcome the avr gene products, thus leading to disease. A study of bean ( $P$. vulgaris) inoculated either with virulent or avirulent races of bean rust (Uromyces appendiculatus), conducted by multidimensional chromatographic separation of the proteome and quantification by spectral counting, indicated that proteins of the basal response did not accumulate to higher levels in the virulent pathogen interaction compared to the avirulent pathogen interaction (Lee et al., 2009). They concluded that basal and $R$-gene-mediated responses occur together and that in the resistant cultivar the $R$-gene products repair the basal defense system, which is inherently strong, rather than acting independently of the effectormediated response (Lee et al., 2009).

All of the important "calorie crops" are monocots, and all are susceptible to fungal pathogens, among which the rusts and powdery mildews occupy an important place. Although much can be gained from studying Arabidopsis pathology, it is a dicotyledonous plant with no rust pathogens. On the other hand, the oomycetes Albugo laibachii and A. candida may prove themselves suitable models (Thines et al., 2009). Progress in crop-rust, crop-mildew, and crop-oomycete proteomics would certainly benefit from research conducted in a robust model system. Numerous proteomics studies using non-crop model systems have contributed tremendously to discovering response patterns in plant-pathogen interactions, which have to be further validated in plants with market importance.

\section{Crop Improvement Against Abiotic Stress: Finding a Way Out}

Understanding the crop response to climate variations has always been the focal theme for agriculturists, agro-meteorologists, plant biologists and environmentalists, as it directly affects the food security (Porter \& Semenov, 2005). In search of higher yield and better grain quality, breeders have developed numerous cultivars through conventional breeding programs. Diverse researches during the last two to three decades have revealed that these cultivars are not potent enough to cope with the present rate of climate change. Wheat production must continue to increase at least $2 \%$ annually until 2020 to meet the future demand, but the major components of climate change [like increases in ozone $\left(\mathrm{O}_{3}\right)$, carbon dioxide $\left(\mathrm{CO}_{2}\right)$, ultraviolet-B (UV- 
B), etc.], increasing drought and salinity, changing soil nutritional dynamics, etc., do not seem to let that happen (Cho et al., 2011; Zargar et al., 2011). Keeping this realistic picture in mind, Dr. Norman Borlaug had concluded that the next era of crop biotechnology would be governed by identifying genotypes that could maximally exploit the future environment for yield enhancement vis-a-vis improved stress tolerant traits (Reynolds \& Borlaug, 2006). Engineering crops for the future requires a basic understanding on the detailed network of induced biomolecular changes in different genotypes of present crops (Ainsworth et al., 2008). Plant acclimation to stress is associated with profound changes in proteome composition. Since proteins are directly involved in plant stress response, proteomic studies can significantly contribute to unravel the possible relationships between protein abundance and plant stress acclimation. Protein response pathways shared by different plant species under various stress conditions. However, studies showed that the major damage in the photosynthetic machinery and primary metabolism pathways are quite similar in all the plants under various stresses (Cho et al., 2011; Zargar et al., 2011).

\section{New Hints From the Proteome of Resurrection Plants}

Climate variability in Southern Africa poses a direct danger to food security in the region with particular respect to maize as it is relatively sensitive to drought (Tschirley et al., 2004). Vegetative desiccation tolerance is a specific trait found in certain species of byrophytes, lichens, ferns, and in a small group of angiosperms known as "resurrection plants" (Gaff, 1989; Oliver, Wood, \& O’Mahony, 1998). Resurrection plants can tolerate more than $95 \%$ loss of their cellular water during dehydration, remain in this state for extended periods, and then regain full metabolic activity upon rehydration (reviewed in Farrant \& Moore, 2011).

To date, few proteomics studies of resurrection plants have been reported during dehydration and rehydration (Ingle et al., 2007; Jiang et al., 2007; Abdalla, Baker, \& Rafudeen, 2010; Oliver et al., 2011). Furthermore, there are few studies in which functional assessment, using biochemical, physiological, and structural studies of proteins are performed to characterize roles of such products in planta (reviewed in Moore et al., 2009; Farrant \& Moore, 2011). Here, we discuss proteomics studies conducted on one indigenous (South Africa) monocotyledonous Xerophyta (Velloziaceae) species, namely $X$. viscosa, as example. Proteomics of $X$. viscosa leaf tissue revealed marked changes in protein expression in two phases (Ingle et al., 2007); the first occurring upon drying to $65 \%$ RWC and the second, more dramatic change occurring when leaves were dried to 35\% RWC (Table 3). These stages (referred to as "early" and "late" stages of protection) correspond to physiological and biochemical changes in Xerophyta species at similar RWCs (Illing et al., 2005; Farrant \& Moore, 2011). Differentially accumulated proteins were found to be involved in antioxidant metabolism, PSII stabilizers, chaperonins, and RNA binding proteins.

Proteomics analysis of the $X$. viscosa nucleus (Abdalla, Thomson, \& Rafudeen, 2009; Abdalla, Baker, \& Rafudeen, 2010) was followed due to the importance of this 
organelle in gene expression and signaling responses (Table 3). The nuclear protein profile of the late dehydration stage was analyzed by 2-DGE-based approach (Abdalla, Baker, \& Rafudeen, 2010). MS analysis of eighteen differentially expressed nuclear protein spots resulted in the identification of proteins associated with gene transcription and regulation, cell signaling, molecular chaperone and proteolysis type activities, protein translation, energy metabolism, and novel proteins. This finding suggests that expression of appropriate stress-response proteins in the nucleus was sufficient to protect the cellular structures during dehydration and in the dried state.

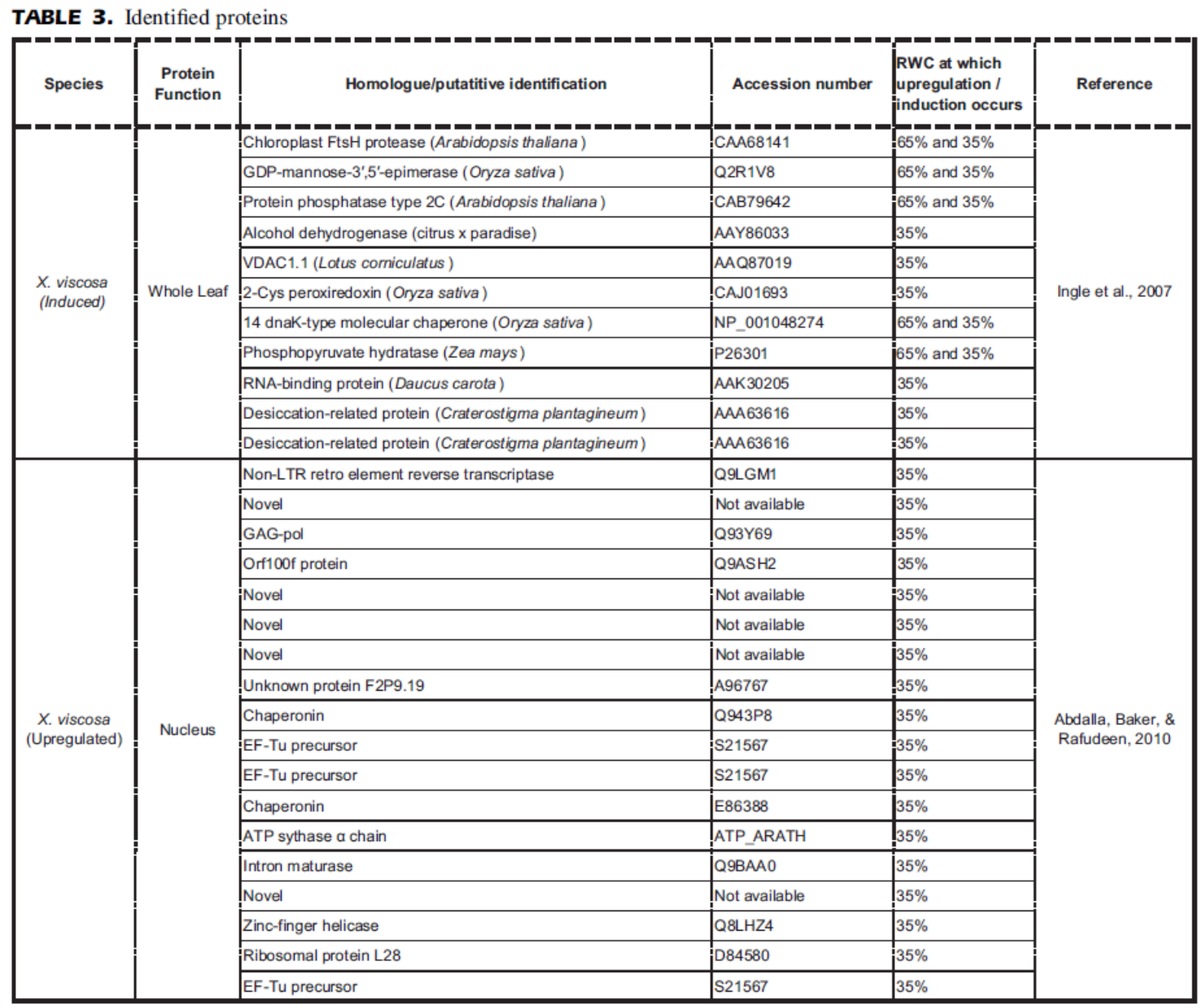

This resurrection plant, although lacking a sequenced genome, is an ideal source of obtaining novel drought-inducible proteins that might be exploited to improve drought tolerance of crop plants (Moore et al., 2009; Farrant \& Moore, 2011).

\section{Protein Oligomerization}

Protein oligomerization is one of the PTMs (Witze et al., 2007). Oligomeric proteinsunless they exist solely or mostly as oligomers-come to exist under the influence of changed concentration, temperature, $\mathrm{pH}$ or through other stimuli such as binding to small or large molecules (nucleotides included) and other PTMs such as phosphorylation or glycosylation, etc. (Ali \& Imperiali, 2005). 
More than $60 \%$ of proteins function in the cell in some kind of a complex with themselves or other proteins. However, what is important to be considered here is conditional change in the oligomerization status of a particular protein that leads to change in function or activity. Abiotic stresses such as drought, heat, high light, chilling, flooding, and salinity quickly change the factors regulating in vivo protein oligomerization, such as temperature, $\mathrm{pH}$, redox status, water content, nutrients, and enzyme substrates. Therefore, before transcriptional responses start and before major energy requirement/consumption changes are noticed, protein oligomerization may be one of the quickest responses to stress conditions, which can change the active enzyme and chaperone complement of the proteome.

For conventional breeding or genetic engineering-mediated improvement in crop plants towards food security issues in the future, the main emphasis will lie on abiotic stress tolerance or yield under various abiotic stresses in general and under drought and salinity in particular. This is especially true for rice because the climate change scenarios predict these two abiotic stresses to be the main reasons for decline in rice yields in future. Hence a comprehensive understanding of plant response to such stress conditions is imperative. Factors such as differential oligomerization mediated changes in the enzyme complement can only be captured through targeted and advanced proteomic approaches, including the study of redox proteomes. Unless methods and protocols are standardized for capturing differential oligomerization of proteins, especially those that do not necessarily change at the transcript level under stress, a part of our understanding of plant response and hence our capacity to modulate it may remain incomplete.

\section{E. Postharvest Proteomics}

The burden to fulfill the increasing food demand has been placed mainly in agriculture through crop improvement. While, crop improvement, without any doubt has a pivotal role to play to meet this demand, broader strategies can play a significant role. For example, especially in developing countries, postharvest losses account significantly that of the total production (Floros, Newsome, \& Fisher, 2010) mainly due to inadequate postharvest management and processing practices. The prediction that food production should be doubled by 2050 probably can be partially circumvented by complementary strategies, such as management of postharvest losses and use of appropriate food processing techniques. In this section, we will focus on current applications of postharvest proteomics to understand and reduce postharvest produce losses. The application of proteomics in postharvest dates back several years. Horticultural crops after being harvested are constantly exposed to stresses of different nature (e.g., mechanical, physical) (Gó mez-Galindo et al., 2007) during handling and transport from the centers of production throughout the whole food supply chain. Envisioning an extended shelf life, many crops are stored in controlled and modified atmospheres (Pedreschi et al., 2010). But postharvest physiological problems cannot be ruled out (Casado-Vela, Selles, \& Bru Martinez, 2005). These physiological 
problems result in huge food and economical losses, which are due to improper handling during harvest and postharvest management. Proteomics has been a useful tool to understand physiological disorders in pears, apples, peaches, and citrus fruits (Lliso et al., 2007; Pedreschi et al., 2007, 2009; Nilo et al., 2010).

There is awareness in the postharvest community that the only way to understand physiological disorders and other post-harvest physiological events affecting quality is through the application of holistic approaches. This would allow early decisions on how to manage the product (e.g., early sale, food processing, etc.). Given the biological complexity involved in understanding the different events for example during ripening (e.g., respiratory changes, volatile compound changes, and ethylene synthesis), and postharvest management (e.g., gas and mass transfer events, temperature control), a systems biology approach (Hertog et al., 2011) is recommended to integrate not only physiological data but biophysical data and models. The potential of systems biology in postharvest applications such as regulation of processes and responses, quality prediction, plant improvement, and virtual crop has been recently emphasized (Hertog et al., 2011).

\section{F. Food Proteomics: Food Analysis and Traceability}

Nutrigenomics and nutrigenetics are two emerging disciplines (Bagchi, Lau, \& Bagchi, 2010) aiming to elucidate how nutrients modulate gene expression, protein synthesis, and metabolism. The difference between the two is subtle but not trivial. Whereas nutrigenomics investigates the impact of nutrients on gene regulation, nutrigenetics studies the effect of genetic variations on individual differences in response to specific food components. In other words, the latter discipline should, in a way, resemble personalized medicine, a future goal of physicians in tailoring drug dosage and drug types to the individual genetic background, as modulated, for example, by single nucleotide polymorphism (SNP). Both disciplines have resulted in the commercial launch of "Nutraceuticals" (a neologism combining the world nutrients and pharmaceuticals) and "functional foods" that could regulate health effects based on individual genetic profiles. Such nutraceuticals should contribute to the prevention of diseases, such as cancer, cardiovascular disease, obesity, and type II diabetes. The Japanese are much advanced in their studies on "functional food," that is, those foods that could improve human health. The Ministry of Health, Labour and Welfare of Japan has already approved 820 such products in total and allowed them to carry labels that make health claims. These health foods have been divided into 11 categories, ranging from modulation of gastrointestinal conditions, of cholesterol levels, of blood pressure, and the like. Well, these authors have explored a number of these foods via Gene Chips and report specific modulation of several genes after intake of the various functional food categories, ranging from soy protein isolates, to sesame seeds, cocoa, royal jelly, and the like. Perhaps plenty of people might find information that could be useful to cure their life-long mini-dysfunctions. 
Curiously, in many recent scientific reports on food analysis, there are scarce proteomic data, most of the work being focused on metabolites, small-molecules mimicking drug function and aromas. Only recently proteomic science has been applied to the exploration of protein components (especially those present in traces) in various types of dietary products. This section will offer a survey of such work, with the provision that it will be limited to the application of combinatorial peptide ligand libraries (CPLLs) to selected foodstuff and beverages in search of trace species that might affect (positively or negatively) human health. Our selection of the CPLL technique is entirely based on literature survey, where this technique was found to be one of the most promising among the enrichment techniques for identification of low-abundance proteins, to dig deeper into proteomes, and applicability to a wide-range of biological samples derived from different organisms including plants. This statement does not necessary mean that other proteomic techniques have not been utilized for studying food proteins; or by any means it is publicity for CPLL. Moreover, space limitation is another constraint.

Combinatorial peptide ligand library (CPLL) is the most recent sample treatment process (Fig. 4) that, from an initial stage of curiosity, is today largely used for the detection of very-low-abundance proteins from a variety of biological extracts. Vast literature on CPLL (reviewed in Righetti et al., 2006; Guerrier, Righetti, \& Boschetti, 2008; Righetti \& Boschetti, 2008; Righetti, Fasoli, \& Boschetti, 2011) indicates the potential of CPLL as an emerging new tool for proper identification of the very low level of food contaminants, as per the requirements of the regulatory agencies. 


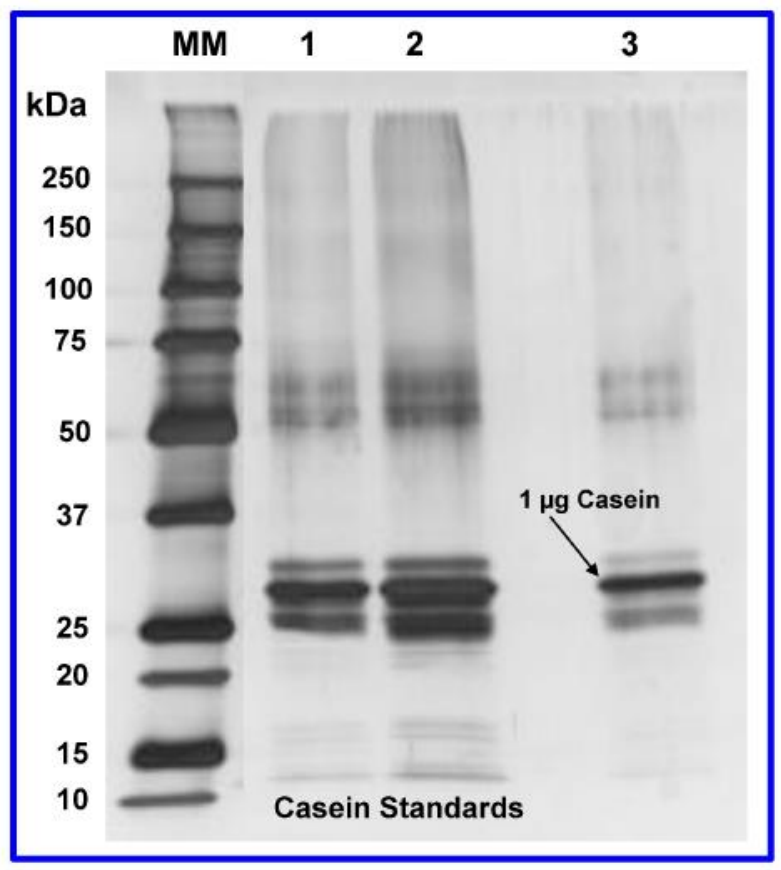

FIGURE 4. As little as $1 \mu \mathrm{g} / \mathrm{L}$ of casein added as fining agent can be efficiently detected in white wines via capture with combinatorial peptide ligand libraries. MM: molecular weight standards. Tracks: 1 and 2: 2 and $5 \mu \mathrm{g}$ casein standards; $3: 1 \mu \mathrm{g}$ casein detected in a fined wine from the Veneto Region (Soave). SDS-PAGE gel, silver stained (modified from Cereda et al., 2010, by permission).

\section{Alcoholic Beverages}

In modern times, it has become customary to fine wines, so as to remove residual grape proteins that might flocculate during storage. Among the fining agents, one of the most popular is casein derived from bovine milk. However, caseins are also known as major food allergens and therefore, according to the Directive 2007/68/EC of the European Community (EC), "any substance used in production of a foodstuff and still present in the finished product" must be declared in the label, especially if it originates from allergenic material. Wine producers have never honored this directive, on the grounds that any residual casein would be below the detection limit set by the EC (200 $\mathrm{mg} / \mathrm{L}$ via indirect ELISA assay). Via the CPLL technique, Cereda et al. (2010) and D'Amato et al. (2010) have been able to detect such residual casein down to as low as $1 \mathrm{mg} / \mathrm{L}$. Thus, it turns out that, if wines have been treated with casein (or with egg albumen), residues of such additives will always be there and detectable via CPLLs, something that the EC rulers should be aware off. This is what can be found in "treated," but what would happen with "untreated" wines? The exploration of the global proteome of wine products would have a quite ambitious aim: to see if, by assessing the global content of a given wine from a producer, one could obtain a proteomic signature (proteo-typing) that might enable its identification against counterfeited products. Especially in the case of "grands crus," counterfeited products are reported more and more frequently to invade the market, with severe damage for both producers and consumers. This has been attempted with a Recioto (a dessert wine produced in the Veneto region in Italy with Garganega grapes): 106 unique gene 
products could be typed via CPLL capture (D'Amato et al., 2011a), something unique considering that in untreated Champagne (from Reims, France) only nine species could be identified (Cilindre et al., 2008) and, in a Chardonnay white wine from Puglia, Italy, just 28 glycoproteins could be detected (Palmisano, Antonacci, \& Larsen, 2010). Whether or not some 100 or so proteins might enable us to distinguish different crus remains to be seen. At the moment, research is progressing on typing of Champagne made with single grapes versus Champagne produced with three grape varieties (Righetti, Cilindre et al., work in progress). By the same token, the beer proteome has been explored via the CPLL methodology, permitting the identification of no less than 22 barley proteins, two maize proteins (this lager beer had been produced with a mixture of the two grains), and $40 \mathrm{~S}$. cerevisiae proteins (Fasoli et al., 2010), the latter present in minute traces and thus escaping detection by conventional techniques.

\section{Non-Alcoholic Beverages}

Supermarket shelves, especially in the USA, are heavily colonized by a huge variety of non-alcoholic beverages, claiming the presence of any possible plant or fruit extract. Yet, nobody has ever analyzed their proteome content, in order to see if such beverages contain a least traces of the plant material from which they are claimed to be produced. Just as an example, ginger drinks (including ales) can be found with an incredible variety of brands and names. Yet, would they contain any ginger root extract? Two types of drinks, very popular all along the Mediterranean countries, have been recently analyzed with the CPLL technique: almond's milk and orgeat syrup (Fasoli et al., 2011). In the first product 137 unique protein species were identified. In the second beverage, a handful of proteins (just 13) were detected, belonging to a bitter almond extract. In both cases, the genuineness of such products was verified, as well as the fact that almond milk, judging on the total protein and fat content, must have been produced with $100 \mathrm{~g}$ ground almonds per liter of beverage, as required by food authorities. On the contrary, cheap orgeat syrups produced by local supermarkets and sold as their own brands, were found not to contain any residual proteins, suggesting that they were produced only with synthetic aromas and no natural plant extracts. By the same token, a commercial coconut milk beverage was analyzed via CPLLs (D’Amato, Fasoli, \& Righetti, 2012). A grand total of 314 unique gene products could be listed, 200 discovered via CPLL capture, 146 detected in the control, untreated material, and 32 species in common between the two sets of data. This unique set of data could be the starting point for nutritionists and researchers involved in nutraceutics for elucidating some proteins responsible for the cornucopia of unique beneficial health effects attributed to coconut milk.

Perhaps one of the most striking results was obtained by Analysis of a cola drink, produced by an English company and stated to be produced with cola nut as well as Agave tequilana extracts. Indeed, a few proteins in the $M_{\mathrm{r}}{ }^{15}$ - to $20-\mathrm{kDa}$ range could be identified by treating large beverage volumes $(1 \mathrm{~L})$ and performing the capture with CPLLs at very acidic $\mathrm{pH}$ values $(\mathrm{pH}$ 2.2) under conditions mimicking reverse-phase 
adsorption (D'Amato et al., 2011b). Ascertaining the presence of proteins deriving from plant extracts has confirmed the genuineness of such beverage and suggests the possibility of certifying whether soft drinks present on the market are indeed made with vegetable extracts or only with artificial chemical fl voring. As a negative control, Coca Cola was analyzed as well. It is generally believed that present-day Coca Cola is indeed a fully artificial beverage, in which neither the coca leaf nor cola nuts extracts are utilized. In fact, when looking at the following drinks at the official Coca Cola web site [Diet Coke, Sprite, Coke 20, Coke Classic, Coca Cola Classic, Coke Zero, Cherry Coke, Fresca, Diet Sprite Zero (partial list)], one can easily obtain this information: protein content, zero; and fat content, zero. An impressive parade of "zeroes," suggesting that no vegetable extracts should be present. As a matter of fact, when applying the same procedure to one liter of Coca Cola beverage, D'Amato et al. (2011b) could not detect any trace of proteins.

In the most recent investigation, the same group of authors has analyzed the proteome of white-wine vinegar (Di Girolamo, D'Amato, \& Righetti, 2011). A total of 27 unique gene products were identified. The most abundant species detected, on the basis of spectral counts, was seen to be the whole genome shotgun sequence of line PN40024, scaffold_22 (a protein of the glycosyl hydrolase family). Curiously, up to the present, no information had been available on the vinegar proteome. These authors also speculated on the possible structure and amino acid composition leading to the survival of just these 27 grape proteins in such an acidic environment ( $\mathrm{pH}$ 2.2), which should in general lead to protein denaturation and precipitation.

\section{Selected Foodstuff}

Even prior to the work on beverages, CPLLs were applied to analysis of some foodstuff of daily consumption. The first one regarded egg white and was deemed a good challenge for CPLLs, due to the fact that a few proteins dominated the landscape and massively masked the signal of low-abundance species; additionally, only a dozen or so proteins had been known in this type of nutriment. By using two types of hexapeptide libraries, terminating either with a primary amine or modified with a terminal carboxyl group, D'ambrosio et al. (2008) identified 148 unique protein species. In a subsequent report, Farinazzo et al. (2009) analyzed the chicken egg yolk cytoplasmic proteome, this time by using also a third CPLL, terminating with a tertiary amine. The results were most exciting: 255 unique protein species were brought to the limelight. These two articles formed the basis of an extensive study on the interactomics of egg white and yolk proteomes (D’Alessandro et al., 2010).

In yet an additional report, the cow's whey proteome was investigated via CPLLs (D'Amato et al., 2009). That study identified a total of 149 unique protein species, of which 100 were not described in any previous proteomics studies. A polymorphic alkaline protein, found only after treatment with CPLLs, was identified as an immunoglobulin (Ig), a minor allergen that had been largely amplified. Donkey's milk was analyzed as well. This milk is today categorized among the best mother milk 
substitute for allergic newborns, due to its much reduced or absent allergenicity, coupled to excellent palatability and nutritional value. By exploiting CPLLs, and treating large volumes (up to $300 \mathrm{~mL}$ ) of defatted, decaseinized (whey) milk, Cunsolo et al. (2011) have been able to identify 106 unique gene products. Due to poor knowledge of the donkey's genome, only $10 \%$ of the proteins could be identified by consulting the database of Equus asinus; the largest proportion (70\%) could be identified by homology with the proteins of Equus caballus.

\section{Food Safety: Hints From Proteomics}

The uniqueness of qualitative/quantitative protein biomarkers might become pivotal also in food testing to determine both food safety and authenticity. On one hand there is interest in knowing which product has been used to produce a specific food, and thus identify the production origin of an aliment of certified and guaranteed "controlled origin." On the other hand there is concern to evaluate its (product) edibility through biochemical assessment of product purity, both under a chemical and microbiological standpoint. As both these concepts are somehow intimately intertwined, proteomics might provide valuable shortcuts to give an answer to both interests.

The recent epidemic of mutant E. coli, which has involved the North of Germany and almost paralyzed vegetable commerce within Europe at the beginning of June 2011, might represent a warning sign. Nonetheless, big strides in the field of MS application to microbiology are still defining an ongoing revolution that might spread its benefits to the food safety endeavor as well: the introduction of Bruker Daltonics' Matrix Assisted Laser Desorption/Ionization (MALDI)-Biotyper (Seng et al., 2009). This technology allows for rapid and accurate identification of bacteria and microorganism (and region-specific substrains) cultured from routine clinical samples through the identification of speciesspecific proteins (Fig. 5). Its application to the field of food safety might result in something more than a suggestive perspective, contributing to the cause of reducing the likelihood of untoward risks rising from the assumption of unsafe food. Quality control becomes a founding principle in the alimentary industry when it comes to GM organisms. Over recent years, it has become clear that food and feed plants carry an inherent risk of contaminating our food supply (Ahmad et al., 2010). The current procedures to assess the safety of food and feeds derived from modern biotechnology include the investigation of possible unintended effects. To improve the probability of detecting unintended effects, proteomics has been utilized as complementary analytical tools to the existing safety assessment; details are mentioned under the subtitle "Assessing the Equivalence of Genetically Modified Crops.”

\section{Assessing the Equivalence of Genetically Modified Crops}

Improving agronomic traits of crops has been a major objective of conventional breeding and modern biotechnology. Plant varieties derived from conventional methods of plant breeding have been commercialized for many years without premarket regulation and assessment. 


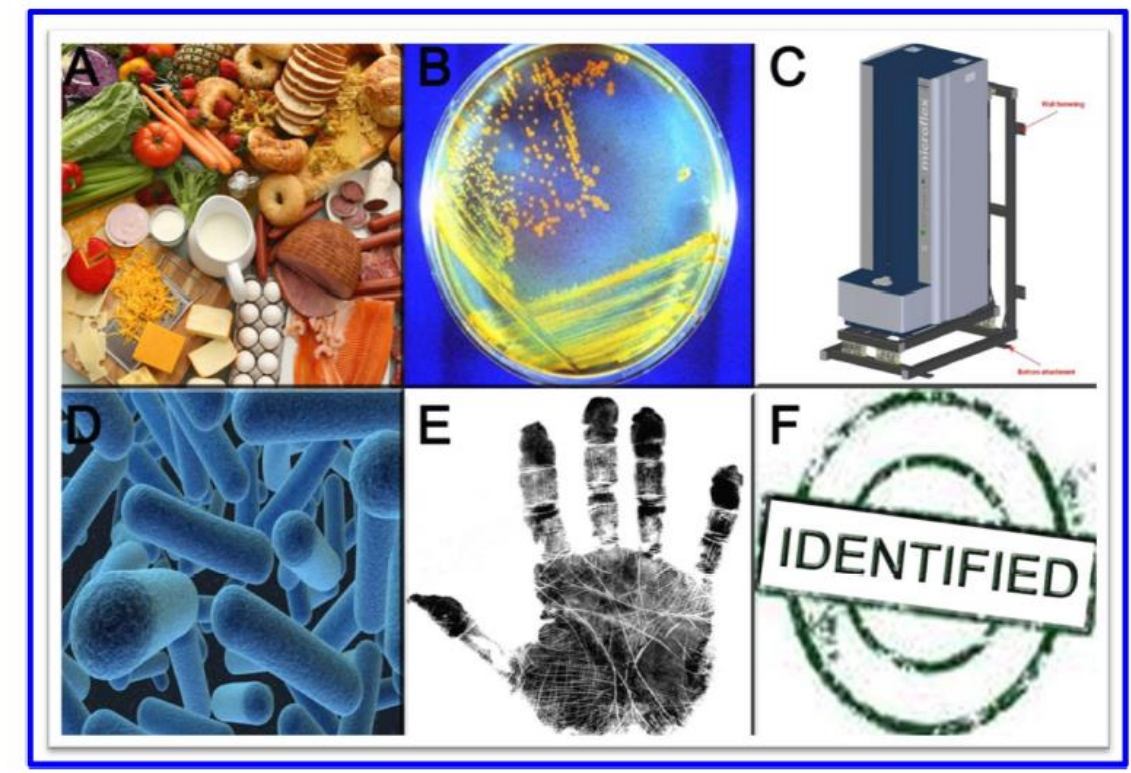

FIGURE 5. Workflow of bacteria identification through the MALDI Biotyper technology. Food safety (A). Manual or automated cultures can be performed starting from food products (B). Cells are then analyzed through MALDI-based MS platforms (C), such as MALDI Biotyper, which associates mass spectra to each bacterium strain and/or sub-strain (D). The concept underpinning this approach is that a peculiar MALDI spectrum profile is associated to each bacterium strain, in a fingerprint like fashion (E), thus it is possible to ultimately identify (F) bacteria through a rapid application of this workflow. Automation of each and every phase of the workflow allows for increasing confidence of the identification of the bacterium strain in a fast and reliable way.

However, GM crops remain highly controversial, notably in Europe. The major issue of concern is the safety of the introduction of new desired traits for humans and animals. The questions arise: (i) does the introduction of genes into a crop recipient cause unintended effects? and (ii) do crops harboring foreign genes have any negative impacts on health? (Cellini et al., 2004; Ruebelt et al., 2006a,b,c; García-Cañ as et al., 2011).

The concept of "substantial equivalence" is the most popular principle for safety assessment of GM crops (OECD, 1993). According to this concept, GM crops should be compared to their conventional counterparts to evaluate whether they have the substantial equivalent components. A primary evaluation method is targeted analyses to uncover variations in some analytes for each crop varieties. However, targeting only some specific analytes does not expose all the unintended effects caused by transgenes (Millstone, Brunner, \& Mayer, 1999). Proteomics has emerged as very useful techniques in evaluating unintended effects (Kuiper, Kok, \& Engel, 2003; Barros et al., 2010; Herrero et al., 2012). Proteins are of great interests in food or feed safety assessment, because of their involvement in metabolism and cellular development. In some cases they can also negatively impact human or animal health, behaving as toxins, anti-nutrients, or allergens. Accordingly, investigation into the proteome would increase the chance to obtain more information about the unintended effects (Lovegrove, Salt, \& Shewry, 2009).

2-DGE combined with MS is the most popularly used techniques in proteomics aimed at GM food safety. Protein profiles of seeds of 12 transgenic Arabidopsis lines expressing different transgenes and their parental line were found to be substantially equivalent 
(Ruebelt et al., 2006a,b,c). In another study, there were no consistent proteome differences in twelve transgenic Arabidopsis lines expressing the bar gene either (Ren et al., 2009). GM crops have also been widely investigated from a proteomic point of view. GM maize MON810 expressing Cry1Ab is one of the most popular GM crops in safety assessment. Coll et al. (2011) showed that there were virtually identical protein patterns between maize MON810 and non-GM lines. However, it was observed that 43 proteins displayed altered abundance levels in maize MON810 (T6) compared to non-transgenic plants (WT6), which could be specifically related to the expression of the transgene (Zolla et al., 2008). Furthermore, by using 2-DGE, Batista and Oliveira (2010) documented the role of natural plant-to-plant variability in observable differences between MON810 and control maize plants. These results disclosed that some of the differences encountered between pools of plants (GM vs. non-GM plants) could be the result of a high plant-to-plant natural variability, which emphasized the importance of assessing

natural variability in safety assessment. When GM pea was studied by 2-DGE combined with MS, 33 proteins were found to be differentially expressed in aAI1containing lines compared with control lines, and 16 proteins were identified by MALDI-time of flight (TOF)-TOF (Chen et al., 2009). Many other GM plants were also subjected to proteomic analysis, such as GM wheat (Di Luccia et al., 2005), potato (Lehesranta et al., 2005), tomato, and tobacco (Corpillo et al., 2004). In contrast, there was little 2-DGE-proteomic information on GM rice to date. Wang et al. (2008) performed a proteomic study on mature embryos of hybrid rice based on 2-DGE and MALDI-TOF-MS analyses, and identified 54 differentially expressed proteins between hybrid rice and parental lines.

Leaf proteomes of $\mathrm{scFv}\left(\mathrm{G}_{4}\right)$-expressing tomato and $\mathrm{scFv}(\mathrm{B} 9)$-expressing tobacco were compared with corresponding non-transgenic plants by $2 \mathrm{D}$-differential in-gel electrophoresis (DIGE) (Di Carli et al., 2009). Of differentially expressed proteins (10 for tomato and 8 for tobacco), PCA showed undefined separation between transgenic plants and controls. It was concluded that the proteomics differences between transgenic and non-transgenic plants were more likely due to physiological variations. This conclusion was confirmed by another study of the effects of transgenic $a \mathrm{AI}$ on proteomes of two pea cultivars carried out by 2D-DIGE (Islam et al., 2009). These authors found that even transformed with the same gene, two transgenic cultivars showed no (at least little) common alterations of protein profiles. Teshima et al. (2010) applied 2D-DIGE to proteomic phenotyping of natural variants in 10 varieties of rice, and showed extensive natural variability of rice seed proteome resulting from different genetic background. Shotgun proteomics has also been used to monitor the protein profiles of natural mutant rice RCN and its wild-type control (Lee et al., 2011). iTRAQ-based shotgun proteomics was used to compare and quantify seed proteomes of transgenic rice expressing hGM-CSF and wild-type control (Luo et al., 2009). 


\section{Plant Biomarkers for Human Health: Examples on Food Allergens}

Significant and rapid advancements have been made in the field of biomarker discovery for human health. With the phenomenal advancement in proteomics technology along with the increased potential of bioinformatics tools, biomarkers have gone from being physical measurements of a particular health or disease state to being precise molecular indicators. Moreover, whereas before individual proteins were used as biomarkers, with some degree of success, now discriminating patterns of proteins observed in a particular proteome are allowing for much earlier and accurate detection of a disease (Johann et al., 2004). A further advantage is that these multiplexed biomarkers compensate for both patient and disease state heterogeneity helping to achieve sufficient clinical efficacy. While much of the progress in molecular biomarker breakthrough employing proteomics has occurred in the fields of cancer and heart disease predisposition and detection (Srinivas, Kramer, \& Srivastava, 2001; Vasan, 2006), it is also being applied successfully in the areas of plant-specific biomarkers for human health and food security. Promising applications are in the field of biomarkers for plant food allergen identification and detection.

In the past decade, there has been a marked increase in food allergies of plant origin recorded around the world but particularly in developed countries, with approximately $5 \%$ of infants in the USA suffering from some form of food allergy (Hadley, 2006), including the well-known baker's asthma (Tathman \& Shewry, 2008). These allergies can present a severe health risk due to the potential of some plant allergens to trigger life threatening immunological reactions resulting in anaphylaxis. It is therefore essential to develop sensitive methods for identifying and quantifying potential plant food allergens, detecting the presence of trace amounts of allergens in processed food and importantly, detecting both the native form of the allergen as well as the form resulting from food processing practices.

Many different plant food allergens have now been identified and characterized by MS-based proteomic analysis, including but not limited to allergens from peanuts, soybean, fenugreek, hazelnut, and wheat flour (Houston et al., 2005; Akagawa et al., 2007; Chassaigne, Norgaard, \& Arjon, 2007; Chassaigne et al., 2009; Weber et al., 2009; Faeste et al., 2010). Proteomics techniques for quantification of the bio-markers have also been employed. Houston et al. (2011) directly quantitated the allergens in different soybean varieties by spectral counting. Other quantitative proteomics techniques, including DIGE, have been employed to determine the allergen biomarker variation between varieties of peanuts (Schmidt et al., 2009), to select for low allergen containing varieties.

Disclosure of the potential allergenicity of food products is essential to ensure human food safety and this is particularly important when a new food product is introduced to the market. Detection of allergenic proteins in foods has traditionally depended on costly immunochemical techniques such as Enzyme-Linked Immuno-Sorbent Assay (ELISA), however, the reliability of the technique was poor, conditional on the 
specificity and stability of the antibodies employed, and recognition was strongly influenced by changes induced in the antigen by processing treatments (Picariello et al., 2011). Differences in antibody specificity also make it difficult to quantify the amounts of the contaminating antigen present in the food, which is essential for safe food labeling practice. Multi-allergen detection and quantification of food allergens at trace levels is aimed (Heick, Fischer, \& Popping, 2011; Heick et al., 2011a) to ensure food safety to the allergenic consumers and be able to reinforce current legislation on the subject (Johnson et al., 2011).

Much of the focus in this area has been toward the identification of nut allergens, and in particular peanuts, in food products due the prevalence and seriousness of this allergy in humans and the wide use of nuts/peanuts as a source of protein in food products. The LC-MS/MS has been used to confirm the presence of a major peanut allergen Ara h1 in ice cream (Shefcheck \& Musser, 2004) as well as to detect the presence of this allergen in dark chocolate (Shefcheck, Callahan, \& Musser, 2006). Other peanut allergens including Ara h2 and Ara h3/4 were detected by LC-MS/MS, employing a triple quadrupole mass analyzer, in food products, such as rice crispy and chocolate-based snack foods (Careri et al., 2007). Several different nut allergens, including Ana o 2 from cashew-nut, Cor a 9 from hazelnut, Pru 1 from almond, Ara h3/4 from peanut, and Jug $\mathrm{r} 4$ from walnut, were identified in cereals and biscuits employing LC-linear ion trap MS/MS (Bignardi et al., 2010). Capillary LC/Q-TOF (MS/MS) was also determined to be a valid approach to detect peanut allergens in processed peanuts (Chassaigne, Norgaard, \& Arjon, 2007). Multiallergen detection of seven allergenic foods (five of plant origin) was feasible through shotgun and targeted SRM MS-based approaches (Heick, Fischer, \& Popping, 2011; Heick et al., 2011a).

The application of proteomics in the field of food allergy biomarker discovery and detection provides cost effective and sensitive techniques that will help to improve food allergy diagnosis, therapy, and allergenic risk assessment.

\section{How we are piping today: an organizational and community-based approach}

Active involvement of organizations (scientific, government, and non-government organizations) is needed to tackle the threatening "the global food security and safety" problem. In the following section, we discuss organizational approaches dealing with food security issues at their own capabilities.

\section{A. International Bodies Related to FoodSecurity Issues}

As the food security crisis is a trans-disciplinary social problem, the premier organizations directly working in this field are mainly societal in framework, that is-inter- and intra- governmental organizations, and non-governmental organizations. The largest among them is the United Nations (UN) dedicated to confront the challenges of the food security crisis at a worldwide level through numerous organizational approaches, like World Food Program (WFP), World Bank (WB), Food and Agricultural organization (FAO), and World Health Organization 
(WHO). There are several other initiatives too, and the majority of them are nongovernmental in nature, like the Rockefeller Foundation, William and Flora Hewlett Foundation, and Bill and Melinda Gates Foundation.

The Consultative Group on International Agricultural Research (CGIAR) established a unique worldwide network of agricultural research centers coordinating and collaborating activities towards the improvement of global agriculture. The first two institutes established by CGIAR were the International Maize and Wheat Improvement Center (CIMMYT; http:// www.cimmyt.org/) and International Rice Research Institute (IRRI; http://www.irri.org/). These organizations have specific scientific interests; but their impact on global food security is commendable starting with the Green Revolution innovations of the late 2oth century that reduced the fraction of the world's hungry from half to less than a sixth, even as the population doubled from 3 to 6 billion. Rice is the most important food crop of the developing world and Asia accounts for $90 \%$ of the global rice production. Over the past 50 years, the research centers of IRRI are continuously and successfully working to improve the rice production quantity and quality worldwide. In an opportune move, in November 2010 IRRI launched a program called Global Rice Science Partnership (GRiSP; http://irri.org/our-science/global-rice-science-partnership-grisp), which is an exemplary, trail-blazing, tour-de-force initiative in coordinating rice research at a global level for optimal inputs and maximal gains towards enhancing rice productivity for food security and poverty alleviation. The core goal of GRiSP is captured in Figure 6, which illustrates basic and applied research, development, extension, and policy promotion centered around the three pillars of sustainability, economic, environmental, and societal benefits. The International Crops Research Institute for the Semi-Arid Tropics (ICRISAT) is another organization that conducts agricultural research for development in Asia and sub-Saharan Africa with a wide array of partners throughout the world. The World Vegetable Center, previously known as Asian Vegetable Research and Development Center (AVRDC), is the international organization specifically dedicated to vegetable research and development. Two organizations working towards agricultural biodiversity and tropical agriculture are also worth noting, namely the Bioversity International (http://www.bioversityinternational.org/) and CIAT (International Center for Tropical Agriculture, http://www.ciat.cgiar.org/Paginas/index.aspx).

\section{International Bodies Related to Proteomics Issues}

In terms of the organizational initiatives in this specific domain, the Human Proteome Organization (HUPO) deserves to be mentioned first (www.hupo.org) (Legrain et al., 2011). Over the last 10 years, HUPO has been instrumental in formulating/initiating diverse coordinated programs, including the Human Proteome Project (HPP) and most recently an initiative on model organism proteomes (iMOP), globally for the sake of human health (for details, see www.hupo.org). However, the global community of plant biologists have been conspicuously absent from such initiatives till the recent past. Over several years, the MASCP was the only global 
initiative in plant proteomics, albeit specifically focused on the model plant Arabidopsis (www.mascproteomics.com). While the Plant Proteomics in Europe (EuPP), group under the European Proteomics Association (EuPA), was a popular and successful initiative, it is concentrated in the European region. To address this point and formulate a global platform for the plant proteomics scientist community, the INPPO (www.inppo.com) was conceived in 2008, and formally founded in 2011 with 10 initiatives (Agrawal et al., 2011, 2012b). Among the major aims of the organization, food security related issues are of top priority. We hope that in the coming future, INPPO initiated projects and programs can successfully help society to find some sustainable solution for global food security and safety (see also Weckwerth, 2011).

\section{Networking: Time to Move United \\ United We Stand, Divided We Fall}

The proverb is probably one of the oldest, but it is the ultimate truth behind human civilization. The concepts of unity and humanity induce us to organize and develop activities and approaches aimed to solve problems or issues faced by the population; whether it-be scientific or societal in nature. In the previous sections, we have discussed some of the approaches; which, in their own capacities, can have significant impact on global food security and safety, and also sustain human development into the future. However, despite these initiatives, the global food crisis is increasing every day.

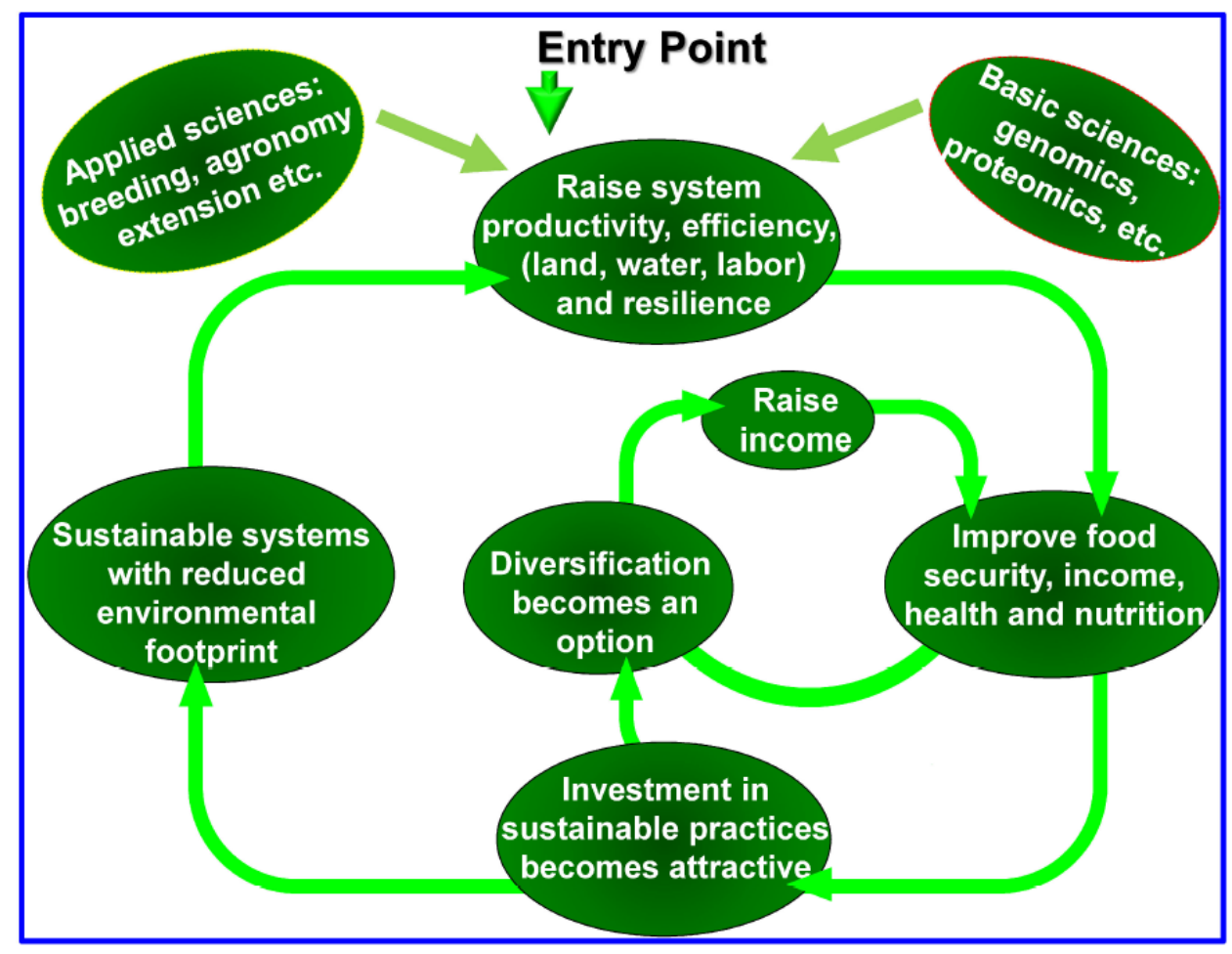

FIGURE 6. Core goal of GRiSP enabling farmers to enter a virtuous circle (adapted from the GRiSP document by Dr. Berta Miro; http://www.ciat.cgiar.org/cgiar/Documents/GRiSP.pdf). 
We need to unite the existing approaches, accelerate their activities, and create a global "network" with a singular aim, global food security and sustainability (Fig. 7). In this cyber age, the meaning of "networking" has become much broader. Different social, professional, and scientific networking sites in World Wide Web have given people an enormous virtual space, where they can not only share their data, but their insight and experiences too. To combat food security issues at an organizational level, we need more than an existing physical network, that is-a virtual network. It is true that most of the above-discussed organizations are focused on their own issues, objectives, agendas, and activities. It might not be a very easy job to make a physical connection/collaboration/ network between them; but, a virtual network for sharing knowledge, experiences and activities is feasible, as all of them, at specific phases, share a common issue "food security and safety"(Fig. 7).

\section{Concluding remarks}

The ever-growing human population and its demand for food were largely met by a "green revolution," and all the biotechnological implications therein to improve seed quality and crop yield. These innovations, however, introduced new and critical problems, such as the isolation or dominance of high-yielding cultivars, in modern day agriculture. A higher demand for food production has forced the so-called "exploitive" agriculture to use more irrigation, fertilizers, and pesticides, and that degrades the natural soil fertility and species biodiversity. As a result, new threats in future food security, sustainability, and safety have appeared. Thus, there is need to set a long-term goal capable of maintaining a balance between human numbers and human capacity to produce food of adequate quantity, quality, and variety. The "evergreen revolution" coined by one of the pioneers of the green revolution, Dr. M. S. Swaminathan, relies on crop biotechnology.

A broader vision, able to integrate the advances in crop biotechnology, postharvest management, and smart food processing technologies might be the answer for a "sustainable green revolution" and food security. Advancements in proteomics technologies in the past decade have seen their tremendous application to burning issues on food security, analysis, safety, and human health as exemplified in this review. The application of proteomics approaches and integration of such into systems biology approaches seem to be the goal to aim for. It is time to come together, form an interdisciplinary global network, share our knowledge, and move together toward developing an efficient strategic roadmap for securing safe and nutritious food and at the same time increasing food production without damaging either biodiversity or the environment. Working together on multiple strategies simultaneously around the globe will be critical for a new and better future 


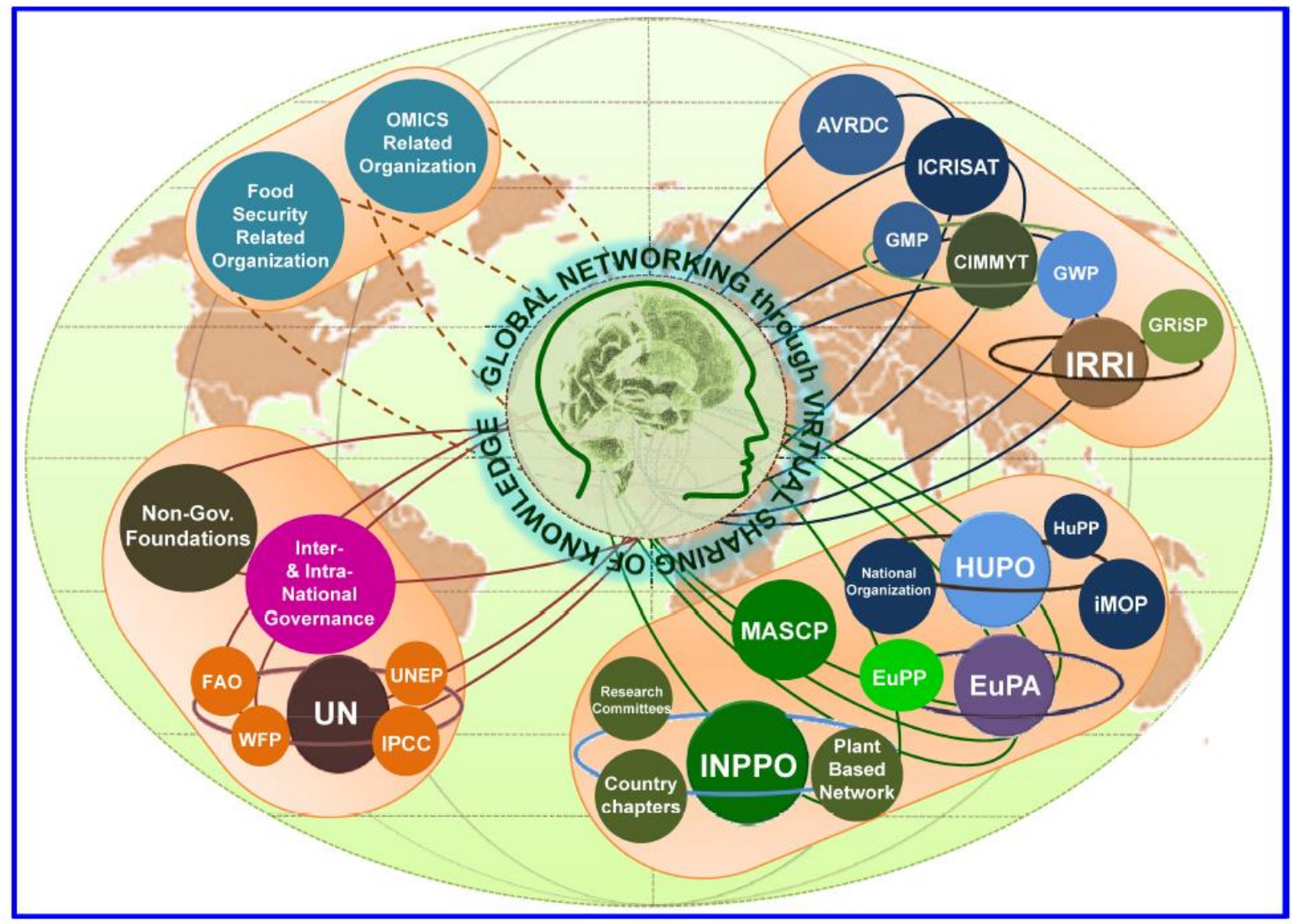

FIGURE 7. There are multiple organizations mainly working for the fundamental, scientific, and societal solutions of solving the global food crisis in their own capacity. But, the increasing crisis in global food storage directly shows that this approach is not enough. We need something more, probably a network of all the organizational approaches. We believe that in this age of Internet communication, we should depend more on networking/sharing our knowledge. Details are in the main text.

\section{ABBREVIATIONS}

$\begin{array}{ll}\text { ALSs } & \text { acid-labile surfactants } \\ \text { AQUA } & \begin{array}{l}\text { absolute quantification } \\ \text { Culture filtrate }\end{array} \\ \text { CPLLs } & \begin{array}{l}\text { combinatorial peptide ligand libraries } \\ \text { cyanine }\end{array} \\ \text { Cy } & \text { one-dimensional gel electrophoresis } \\ \text { 1-DGE } & \begin{array}{l}\text { two-dimensional gel electrophoresis } \\ \text { 2-DGE }\end{array} \\ \text { DIGE } & \text { differential in-gel electrophoresis } \\ \text { ECD } & \text { electron capture dissociation } \\ \text { ELISA } & \text { enzyme-linked immunosorbent assay } \\ \text { EST } & \text { expressed sequence tag } \\ \text { EuPA } & \text { Europe Proteomics Organization } \\ \text { EuPP } & \text { plant proteomics in Europe } \\ \text { FTMS } & \text { Fourier transform mass spectrometry } \\ \text { HPE } & \text { high-performance electrophoresis } \\ \text { HPP } & \text { Human Proteome Project } \\ \text { HUPO } & \text { Human Proteome Organization }\end{array}$




$\begin{array}{ll}\text { ICAT } & \text { isotope-coded affinity tag } \\ \text { iMOP } & \text { initiative on model organism proteomes } \\ \text { INPPO } & \text { International Plant Proteomics Organization } \\ \text { IPG } & \text { immobilized pH gradient } \\ \text { iTRAQ } & \text { isobaric tag for relative and absolute quantitation } \\ \text { LC } & \text { liquid chromatography } \\ \text { MALDI } & \text { matrix assisted laser desorption/ionization } \\ \text { MAMPs } & \text { microbe-associated molecular patterns } \\ \text { MASCP } & \text { Multinational Arabidopsis Steering Committee Proteomics Subcommittee } \\ \text { MDLC } & \text { multidimensional chromatography } \\ \text { MRM } & \text { multiple reaction monitoring } \\ \text { MS } & \text { mass spectrometry } \\ \text { MS/MS } & \text { tandem mass spectrometry } \\ \text { NBS-LRR } & \text { nucleotide-binding site leucine-rich repeat } \\ \text { NMR } & \text { nuclear magnetic resonance } \\ \text { OGE } & \text { off-gel electrophoresis } \\ \text { ORF } & \text { open reading frame } \\ \text { PCR } & \text { polymerase chain reaction } \\ \text { PMF } & \text { peptide mass fingerprints } \\ \text { PR } & \text { pathogenesis related } \\ \text { PTMs } & \text { posttranslational modifications } \\ \text { REMMA } & \text { reconstructed molecular mass analysis } \\ \text { RP } & \text { reverse phase } \\ \text { SCX } & \text { strong cation exchange SDS-PAGE sodium dodecyl sulfate } \\ \text { SILAC } & \text { stable isotope labeling with amino acids in cell culture } \\ \text { SNP } & \text { single nucleotide polymorphism } \\ \text { SRM } & \text { selective reaction monitoring } \\ \text { TSP } & \text { total soluble proteins } \\ \text { UPLC } & \text { ultra-performance liquid chromatography } \\ & \end{array}$

\section{Acknowledgments}

G.K.A. appreciates the Japan Society for the Promotion of Science (JSPS; ID Number S-10182) for his stay and research at Plant Genome Research Unit (NIAS, Tsukuba, Japan). AS acknowledges financial help from the Council of Scientific \& Industrial Research (CSIR), New Delhi, India, in the form of CSIR-Senior Research Fellowship-during his stay and work at BHU. B.J.B. acknowledges DGAPA (grant IN212410) and CONACyT (grant 49735) which support proteomics studies in her laboratory. The research work in the laboratory of R.C. has been supported by the BBSRC (grant BB/Hoo1948/ 1). R.C. and L.V.B. thank Jim Dunwell and Shridar Jambargi for providing hydroponically grown and labeled $F$. vesca plants. L.Z. thanks COFIN-PRIN 20087ATS57 "Food allergenes". T.W. was supported by the Chinese transgenic project (grant 2008ZXo8012-002). RR acknowledges the great support of Professors Yoshihiro Shiraiwa (Chairperson, Faculty of Life and Environmental Sciences, University of Tsukuba) and Seiji Shioda and Dr. Tetsuo Ogawa (Department 
of Anatomy I, Showa University School of Medicine) in promoting interdisciplinary research and unselfish encouragement. Authors acknowledge the INPPO platform for this initiative in bringing together scientists of different disciplines in constructing this review. Finally, given the vast amount of research in these disciplines and space limitations, many works could not be cited and discussed in this review. 


\section{References}

Abdalla KA, Thomson JA, Rafudeen MS. 2009. Protocols for nuclei isolation and nuclear protein extraction from the resurrection plant Xerophyta viscosa for proteomic studies. Anal Biochem 384:365-367.

Abdalla KA, Baker B, Rafudeen MS. 2010. Proteomic analysis of nuclear proteins during dehydration of the resurrection plant Xerophyta viscosa. Plant Growth Regul 62:279-292.

Adav SS, Ravindran A, Sze SK. 2012. Quantitative proteomic analysis of lignocellulolytic enzymes by Phanerochaete chrysosporium on different lignocellulosic biomass. J Proteomics 75:1493-2504.

Aebersold R, Mann M. 2003. Mass spectrometry-based proteomics. Nature 422:198-207.

Agrawal GK, Rakwal R. 2008a. Plant proteomics: Technologies, strategies, and applications. In: Agrawal GK, Rakwal R, editors. Hoboken, NJ, USA: John Wiley \& Sons, Inc.

Agrawal GK, Rakwal R. 2008b. Rice proteomics at a glance. In: Agrawal GK, Rakwal R, editors. Plant proteomics: Technologies, strategies, and applications, Chapter 11. Hoboken, NJ, USA: John Wiley \& Sons, Inc., pp 165-178.

Agrawal GK, Rakwal R. 2011. Rice proteomics: A move toward expanded proteome coverage to comparative and functional proteomics uncovers the mysteries of rice and plant biology. Proteomics 11: 1630-1649.

Agrawal GK, Jwa NS, Iwahashi Y, Yonekura M, Iwahashi H, Rakwal R. 2006. Rejuvenating rice proteomics: Facts, challenges, and visions. Proteomics 6:55495576.

Agrawal GK, Jwa NS, Rakwal R. 2009. Rice proteomics: End of phase I and beginning of phase II. Proteomics 9:935-963.

Agrawal GK, Jwa NS, Lebrun MH, Job D, Rakwal R. 2010. Plant secretome: Unlocking secrets of the secreted proteins. Proteomics 10: 799-827.

Agrawal GK, Job D, Zivy M, Agrawal VP, Bradshaw RA, Dunn M, Haynes PA, van Wijk KJ, Kikuchi S, Renaut J, Weckwerth W, Rakwal R. 2011. Time to articulate a vision for the future of plant proteomics-A global perspective: An initiative for establishing the International Plant Proteomics Organization (INPPO). Proteomics 11:1559-1568.

Agrawal GK, Pedreschi R, Barkla BJ, Bindschedler LV, Cramer R, Sarkar A, Renaut J, Job D, Rakwal R. 2012a. Translational plant proteomics: A perspective. J Proteomics 75:4588-4601.

Agrawal GK, Sarkar A, Agrawal R, Ndimba BK, Tanou G, Dunn MJ, Kieselbach T, Cramer R, Wienkoop S, Chen S, Rafudeen MS, Deswal R, Barkla BJ, Weckwerth W, Heazlewood JL, Renaut J, Job D, Chakraborty N, Rakwal R. 2012b. Boosting the globalization of plant proteomics through INPPO: Current developments and future prospects. Proteomics 12:359-368.

Ahmad A, Pereira EO, Conley AJ, Richman AS, Menassa R. 2010. Green biofactories: Recombinant protein production in plants. Recent Pat Biotechnol 4:242-259. 
Ainsworth EA, Beier C, Calfapietra C, Ceulemans R, Durand-Tardif M, Farquhar GD, Godbold DL, Hendrey GR, Hickler T, Kaduk J, Karnosky DF, Kimball BA, Kö rner C, Koorneef M, Lafarge T. 2008. Next generation of elevated $\left[\mathrm{CO}_{2}\right]$ experiments with crops: A critical investment for feeding the future world. Plant Cell Environ 31:1317- 1324.

Akagawa M, Handoyo T, Ishii T, Kumazawa S, Morita N, Suyama K. 2007. Proteomic analysis of wheat flour allergens. J Agric Food Chem 55:6863-6870.

Alban A, Currie I, Lewis S, Stone T, Sweet AC. 2002. 2-D DIGE- Accurate quantitative proteome analysis: Application of an internal standard to 2dimensional electrophoresis. Mol Biol Cell 13:407A- 408A.

Alban A, David SO, Bjorkesten L, Andersson C, Sloge E, Lewis S, Currie I. 2003. A novel experimental design for comparative two-dimensional gel analysis: Twodimensional difference gel electrophoresis incorporating a pooled internal standard. Proteomics 3:36-44.

Ali MH, Imperiali B. 2005. Protein oligomerization: How and why. Bioorg Med Chem 13:5013-5020.

America AHP, Cordewener JHG. 2008. Comparative LC-MS: A landscape of peaks and valleys. Proteomics 8:731-749.

Amey RC, Schleicher T, Slinn A, Lewis M, Macdonald H, Neill SJ, Spencer-Phillips PTN. 2008. Proteomic analysis of a compatible interaction between Pisum sativum (pea) and the downy mildew pathogen Peronospora viciae. Eur J Plant Pathol 122:41-55.

Ansong C, Purvine SO, Adkins JN, Lipton MS, Smith RD. 2008. Proteogenomics: Needs and roles to be filled by proteomics in genome annotation. Brief Funct Genomic Proteomic 7:50-62.

Armengaud J. 2010. Proteogenomics and systems biology: Quest for the ultimate missing parts. Expert Rev Proteomics 7:65-77.

Arsova B, Kierszniowska S, Schulze WX. 2012. The use of heavy nitrogen in quantitative proteomics experiments in plants. Trends Plant Sci 17:102-112.

Bagchi D, Lau FC, Bagchi M. 2010. Genomics, proteomics, and metabolomics in nutraceuticals and functional foods. In: Bagchi D, Lau FC, Bagchi M, editors. Ames: Wiley-Blackwell. pp 3-338.

Barfoot P, Brookes G. 2007. Global impact of biotech crops: Socioeconomic and environmental effects. 1996-2006. AgBioForum 11: 21-38.

Barkla BJ, Vera-Estrella R, Herná ndez-Coronado M, Pantoja O. 2009. Quantitative proteomics of the tonoplast reveals a role for glycolytic enzymes in salt tolerance. Plant Cell 21:4044-4058.

Barros E, Lezar S, Anttonen MJ, van Dijk JP, Rohlig RM, Kok EJ, Engel KH. 2010. Comparison of two GM maize varieties with a near-isogenic non-GM variety using transcriptomics, proteomics and metabolomics. Plant Biotechnol J 8:436-451.

Batista R, Oliveira M. 2010. Plant natural variability may affect safety assessment data. Regul Toxicol Pharmacol 58:S8-S12.

Becher D, Buettner K, Moche M, Hessling B, Hecker M. 2011. From the genome sequence to the protein inventory of Bacillus subtilis. Proteomics 11:2971-2980. 
Bignardi C, Elviri L, Penna A, Careri M, Mangia A. 2010. Particle-packed column versus silica-based monolithic column for liquid chromatography-electrospray-linear ion trap-tandem mass spectrometry multiallergentrace analysis in foods. $\mathrm{J}$ Chromatogr A 1217:7579- 7585.

Bindschedler LV, Cramer R. 2011a. Quantitative plant proteomics. Proteomics 11:756-775.

Bindschedler LV, Cramer R. 2011b. Fully automated software solution for protein quantitation by global metabolic labeling with stable isotopes. Rapid Commun Mass Spectrom 25:1461-1471.

Bindschedler LV, Palmblad M, Cramer R. 2008. Hydroponic isotope labelling of entire plants (HILEP) for quantitative plant proteomics: An oxidative stress case study. Phytochemistry 69:1962-1972.

Bindschedler LV, McGuffin LJ, Burgis TA, Spanu PD, Cramer R. 2011. Proteogenomics and in silico structural and functional annotation of the barley powdery mildew Blumeria graminis f. sp hordei. Methods 54:431-440.

Bjellqvist B, Ek K, Righetti PG, Gianazza E, Görg A, Westermeier R, Postel W. 1982. Isoelectric-focusing in immobilized $\mathrm{pH}$ gradients- principle, methodology and some applications. J Biochem Biophys Methods 6:317-339.

Bodzon-Kulakowska A, Bierczynska-Krzysik A, Dylag T, Drabik A, Suder P, Noga M, Jarzebinska J, Silberring J. 2007. Methods for samples preparation in proteomic research. J Chromatogr B 849:1- 31.

Boller T, Felix G. 2009. A renaissance of elicitors: Perception of microbe-associated molecular patterns and danger signals by pattern-recognition receptors. Annu Rev Plant Biol 60:379-406.

Bond AE, Row PE, Dudley E. 2011. Post-translation modification of proteins: Methodologies and applications in plant sciences. Phytochemistry 72:975-996.

Bradshaw RA. 2008. An introduction to proteomics: Applications to plant biology. In: Agrawal GK, Rakwal R, editors. Plant proteomics: Technologies, strategies, and applications. Hoboken, NJ: John Wiley \& Sons, Inc. pp 1-6.

Bradshaw RA, Burlingame A. 2005. From proteins to proteomics. IUBMB Life 57:267-272.

Brä utigam A, Shrestha RP, Whitten D, Wilkerson CG, Carr KM, Froehlich JE, Weber AP. 2008. Low-coverage massively parallel pyrosequencing of cDNAs enables proteomics in non-model species: Comparison of a species-specific database generated by pyrosequencing with databases from related species for proteome analysis of pea chloroplast envelopes. J Biotechnol 136:44-53.

Bringans S, Hane JK, Casey T, Tan KC, Lipscombe R, Solomon PS,

Oliver RP. 2009. Deep proteogenomics; high throughput gene validation by multidimensional liquid chromatography and mass spectrometry of proteins from the fungal wheat pathogen Stagonospora nodorum. BMC Bioinformatics 10:301.

Brookes G, Barfoot P. 2009. Global impact of biotech crops: Income and production effects. 1996-2007. AgBioForum 12:184-208.

Cá novas FM, Dumas-Gaudot E, Recorbet G, Jorrin J, Mock HP, Rossignol M. 2004. Plant proteome analysis. Proteomics 4:285-298.

Careri M, Costa A, Elviri L, Lagos JB, Mangia A, Terenghi M, Cereti A, Perono Garoffo L. 2007. Use of specific peptide biomarkers for quantitative confirmation of hidden 
allergenic peanut proteins Ara h 2 and Ara $\mathrm{h}$ 3/4 for food control by liquid chromatography-tandem mass spectrometry. Anal Bioanal Chem 389:1901-1907.

Carpentier SC, Witters E, Laukens K, Deckers P, Swennen R, Panis B. 2005. Preparation of protein extracts from recalcitrant plant tissues: An evaluation of different methods for two-dimensional gel electrophoresis analysis. Proteomics 5:2497-2507.

Carpentier SC, Panis B, Vertommen A, Swennen R, Sergeant K, Renaut J, Laukens K, Witters E, Samyn B, Devreese B. 2008a. Proteome analysis of non-model plants: A challenging but powerful approach. Mass Spectrom Rev 27:354-377.

Carpentier SC, Coemans B, Podevin N, Laukens K, Witters E, Matsumura H, Terauchi R, Swennen R, Panis B. 2008b. Functional genomics in a non-model crop: Transcriptomics or proteomics? Physiol Plant 133:117-130.

Carpentier SC, Pants B, Renaut J, Samyn B, Vertommen A, Vanhove AC, Swennen R, Sergeant K. 2011. The use of 2D-electrophoresis and de novo sequencing to characterize inter- and intra-cultivar protein polymorphisms in an allopolyploid crop. Phytochemistry 72:1243- 1250.

Carr D. 2002. Handbook of analysis and purification of peptides and proteins by reversedphase HPLC. Hesperia, CA, USA: Grace Vydac.

Casado-Vela J, Sellés S, Bru Mart'́nez, R. 2005. Proteomic approach to blossom-end rot in tomato fruits (Lycopersicon esculentum M.): Antioxidant enzymes and the pentose phosphate pathway. Proteomics 5:2488-2496.

Castellana N, Bafna V. 2010. Proteogenomics to discover the full coding content of genomics: A computational perspective. J Proteomics 73:2124-2135.

Castellana NE, Payne SH, Shen Z, Stanke M, Bafna V, Briggs SP. 2008. Discovery and revision of Arabidopsis genes by proteogenomics. Proc Natl Acad Sci USA 105:21034-21038.

Castellana NE, Pham V, Arnott D, Lill JR, Bafna V. 2010. Template proteogenomics: Sequencing whole proteins using an imperfect database. Mol Cell Proteomics 9:1260-1270.

Cellini F, Chesson A, Colquhoun I, Constable A, Davies HV, Engel KH, Gatehouse AMR, Kä renlampi S, Kok EJ, Leguay JJ, Lehesranta S, Noteborn HPJM, Pedersen J, Smith M. 2004. Unintended effects and their detection in genetically modified crops. Food Chem Toxicol 42:1089-1125.

Cereda A, Kravchuk AV, D’Amato A, Bachi A, Righetti PG. 2010. Proteomics of wine additives: Mining for the invisible via combinatorial peptide ligand libraries. J Proteomics 73:1732-1739.

Chassaigne H, Nörgaard JV, Arjon J. 2007. Proteomics-based approach to detect and identify major allergens in processed peanuts by capillary LC-Q-TOF (MS/MS). J Agric Food Chem 55:4461-4473.

Chassaigne H, Tregoat V, Nö rgaard JV, Maleki SJ, van Hengel AJ. 2009. Resolution and identification of major peanut allergens using a combination of fluorescence twodimensional differential gel electrophoresis, Western blotting and Q-TOF mass spectrometry. J Proteomics 72:511-526.

Chen HC, Bodulovic G, Hall PJ, Moore A, Higgins TJV, Djordjevic MA, Rolfe BG. 2009. Unintended changes in protein expression revealed by proteomic analysis of seeds 
from transgenic pea expressing a bean alpha-amylase inhibitor gene. Proteomics 9:4406-4415.

Cho K, Tiwari S, Agrawal SB, Torres NL, Agrawal M, Sarkar A, Shibato J, Agrawal GK, Kubo A, Rakwal R. 2011. Tropospheric ozone and plants: Absorption, responses, and consequences. Rev Environ Contam Toxicol 212:61-111.

Cilindre C, Jé gou S, Hovasse A, Schaeffer C, Castro AJ, Clé ment C, Van Dorsselaer A, Jeandet P, Marchal R. 2008. Proteomic approach to identify champagne wine proteins as modified by Botryotitis cinerea infection. J Proteome Res 7:1199-1208.

Clay J. 2011. Freeze the footprint of food. Nature 475:287-289.

Coll A, Nadal A, Rossignol M, Puigdomènech P, Pla M. 2011. Proteomic analysis of MON810 and comparable non-GM maize varieties grown in agricultural fields. Transgenic Res 20:939-949.

Corbin RW, Paliy O, Yang F, Shabanowitz J, Platt M, Lyons CE Jr, Root K, McAuliffe J, Jordan MI, Kustu S, Soupene E, Hunt DF. 2003. Toward a protein profile of Escherichia coli: Comparison to its transcription profile. Proc Natl Acad Sci USA 100:9232-9237.

Corpillo D, Gardini G, Vaira AM, Basso M, Aime S, Accotto GR, Fasano M. 2004. Proteomics as a tool to improve investigation of substantial equivalence in genetically modified organisms: The case of a virus-resistant tomato. Proteomics 4:193-200.

Coruzzi GM, Rodrigo A, Guttierrez RA. 2009. Plant systems biology. In: Coruzzi GM, Rodrigo A, Guttierrez RA, editors. Annual plant reviews, Vol. 35. Oxford, UK: WileyBlackwell.

Council Regulation 315/93. 1993. Council regulation (EEC) No. 315/93 of 8th February 1993 laying down community procedure for contaminants in food. Off $\mathrm{J}$ Eur Communities L037:1-3.

Cunsolo V, Muccilli V, Fasoli E, Saletti R, Righetti PG, Foti S. 2011. Poppea's bath liquor: The secret proteome of she-donkey's milk. J Proteomics 74:2083-2099.

D’Alessandro A, Righetti PG, Fasoli E, Zolla L. 2010. The egg white and yolk interactomes as gleaned from extensive proteomic data. J Proteomics 73:1028-1042.

D’Amato A, Bachi A, Fasoli E, Boschetti E, Peltre G, Sé né chal H, Righetti PG. 2009. Indepth exploration of cows whey proteome via combinatorial peptide ligand libraries. $\mathrm{J}$ Proteome Res 8:3925-3936.

D’Amato A, Kravchuk AV, Bachi A, Righetti PG. 2010. Noah's nectar: The proteome content of a glass of red wine. J Proteomics 73:2370- 2377.

D'Amato A, Fasoli E, Kravchuk AV, Righetti PG. 2011a. Mehercules, adhuc Bacchus! The debate on wine proteomics continues. J Proteome Res 10:3789-3801.

D'Amato A, Fasoli E, Kravchuk AV, Righetti PG. 2011b. Going nuts for nuts? The trace proteome of a cola drink, as detected via combinatorial peptide ligand libraries. J Proteome Res 10:2684-2686.

D'Amato A, Fasoli E, Righetti PG. 2012. Harry Belafonte and the secret proteome of coconut milk. J Proteomics 75:914-920.

D’Ambrosio C, Arena S, Scaloni A, Guerrier L, Boschetti E, Mendieta ME, Citterio A, Righetti PG. 2008. Exploring the chicken egg white proteome with combinatorial peptide ligand libraries. J Proteome Res 7:3461-3474. 
D’Hont A, Denoeud F, Aury JM, Baurens FC, Carreel F, Garsmeur O, Noel B, Bocs S, Droc G, Rouard M, Da Silva C, Jabbari K, Cardi C, Poulain J, Souquet M, Labadie K, Jourda C, Lengellé J, Rodier-Goud M, Alberti A, Bernard M, Correa M, Ayyampalayam S, Mckain MR, Leebens-Mack J, Burgess D, Freeling M, Mbé guié A-Mbé guié D, Chabannes M, Wicker T, Panaud O, Barbosa J, Hr ibová E, HeslopHarrison P, Habas R, Rivallan R, Francois P, Poiron C, Kilian A, Burthia D, Jenny C, Bakry F, Brown S, Guignon V, Kema G, Dita M, Waalwijk C, Joseph S, Dievart A, Jaillon O, Leclercq J, Argout X, Lyons E, Almeida A, Jeridi M, Dolež el J, Roux N, Risterucci AM, Weissenbach J, Ruiz M, Glaszmann JC, Qué tier F, Yahiaoui N, Wincker P. 2012. The banana (Musa acuminata) genome and the evolution of monocotyledonous plants. Nature 488:213-217.

Damerval C, Devienne D, Zivy M, Thiellement H. 1986. Technical improvements in twodimensional electrophoresis increase the level of genetic-variation detected in wheatseedling proteins. Electrophoresis 7:52-54.

Di Carli M, Villani ME, Renzone G, Nardi L, Pasquo A, Franconi R, Scaloni A, Benvenuto E, Desiderio A. 2009. Leaf proteome analysis of transgenic plants expressing antiviral antibodies. J Proteome Res 8:838-848.

Di Girolamo F, D’Amato A, Righetti PG. 2011. Horam nonam exclamavit: sitio. The trace proteome of your daily vinegar. J Proteomics 75: 718-724.

Di Luccia A, Lamacchia C, Fares C, Padalin L, Mamone G, La Gatta B, Gambacorta G, Faccia M, Di Fonzo N, La Notte E. 2005. A proteomic approach to study protein variation in GM durum wheat in relation to technological properties of semolina. Annal Chim 95:405-414.

Dodds P, Lawrence GJ, Catanzariti A, Teh T, Wang CI, Ayliffe MA, Kobe B, Ellis JG. 2006. Direct protein interaction underlies gene-for-gene specificity and coevolution of the flax resistance genes and flax rust virulence genes. Proc Natl Acad Sci USA 103:8888-8893.

Draper J, Mur LAJ, Jenkins G, Ghosh-Biswas GC, Bablak P, Hasterok R, Routledge AP. 2001. Brachypodium distachyon. A new model system for functional genomics in grasses. Plant Physiol 127:1539- 1555.

Ephritikhine G, Ferro M, Rolland N. 2004. Review: Plant membrane proteomics. Plant Physiol Biochem 42:943-962.

Faeste CK, Christians U, Egaas E, Jonscher KR. 2010. Characterization of potential allergens in fenugreek (Trigonella foenum-graecum) using patient sera and MS-based proteomic analysis. J Proteomics 73: 1321-1333.

FAO. 2009. How to feed the world in 2050, high-level expert forum. Rome: Food and Agriculture Organization of the United Nations.

FAO. 2010. The State of Food Insecurity in the World: Addressing food insecurity in protracted crises. ISBN 978-92-5-106610-2. Rome: Food and Agriculture Organization of the United Nations.

Farinazzo A, Restuccia U, Bachi A, Guerrier L, Fortis F, Boschetti E, Fasoli E, Citterio A, Righetti PG. 2009. Chicken egg yolk cytoplasmic proteome, mined via combinatorial peptide ligand libraries. J Chromatogr A 1216:1241-1252. 
Farrant JM, Moore JP. 2011. Programming desiccation-tolerance: From plants to seeds to resurrection plants. Curr Opin Plant Biol 14: 340-345.

Fasoli E, Aldini G, Regazzoni L, Kravchuk AV, Citterio A, Righetti PG. 2010. Les Ma îtres de l'Orge: The proteome content of your beer mug. J Proteome Res 9:5262-5269.

Fasoli E, D'Amato A, Kravchuk AV, Citterio A, Righetti PG. 2011. In-depth proteomic analysis of non-alcoholic beverages with peptide ligand libraries. I: Almond milk and orgeat syrup. J Proteomics 74:1080-1090.

Feuillet C, Leach JE, Rogers J, Schnable PS, Eversole K. 2010. Crop genome sequencing: Lesions and rationales. Trends Plant Sci 16: 77-88.

Finnie C. 2006. Plant proteomics. In: Finnie C, editor. Hoboken, NJ: John Wiley \& Sons, Inc.

Flavell R. 2010. From genomics to crop breeding. Nat Biotechnol 28:144- 145.

Flor HH. 1971. Current status of the gene-for-gene concept. Annu Rev Phytopathol 9:272296.

Floros JD, Newsome R, Fisher W, Barbosa-Canovas GV, Chen H, Dunne CP, German JB, Hall RL, Heldman DR, Karwe MV, Knabel SJ, Labuza TP, Lund DB, NewellMcGloughlin M, Robinson JL, Sebranek JG, Shewfelt RL, Tracy WF, Weaver CM, Ziegler GR. 2010. Feeding the world today and tomorrow: The importance of food science and technology-An IFT scientific review. Compr Rev Food Sci Technol 9:128.

Fukushima A, Kusano M, Redestig H, Arita M, Saito K. 2009. Integrated omics approaches in plant systems biology. Curr Opin Chem Biol 13:532-538.

Gaff DF. 1989. Responses of desiccation tolerant 'resurrection' plants to water deficit. In: Kreeb KH, Richter H, Hinckley TM, editors.

Adaptation of plants to water and high temperature stress. The Hague: Academic Publishing. pp 207-230.

Gao J, Agrawal GK, Thelen JJ, Xu D. 2009. P3DB a plant protein phosphorylation database. Nucleic Acids Res 37:D960-D962.

Garcíia-Cañ as V, Simó C, Leó n C, Ibá ñ ez E, Cifuentes A. 2011. MS-based analytical methodologies to characterize genetically modified crops. Mass Spectrom Rev 30:396-416.

Gianazza E, Righetti PG. 2009. Immobilized pH gradients. Electrophoresis 30:S112-S121.

Gibon Y, Blaesing OE, Hannemann J, Carillo P, Hö hne M, Hendriks JH, Palacios N, Cross J, Selbig J, Stitt M. 2004. A robot-based platform to measure multiple enzyme activities in Arabidopsis using a set of cycling assays: Comparison of changes of enzyme activities and transcript levels during diurnal cycles and in prolonged darkness. Plant Cell 16:3304-3325.

Gilar M, Olivova P, Daly AE, Gebler JC. 2005. Two-dimensional separation of peptides using RP-RP-HPLC system with different $\mathrm{pH}$ in first and second separation dimensions. J Sep Sci 28:1694-1703.

Goff SA, Ricke D, Lan TH, Presting G, Wang R, Dunn M, Glazebrook J, Sessions A, Oeller P, Varma H, Hadley D, Hutchison D, Martin C, Katagiri F, Lange BM, Moughamer T, Xia Y, Budworth P, Zhong J, Miguel T, Paszkowski U, Zhang S, Colbert M, Sun WL, Chen L, Cooper B, Park S, Wood TC, Mao L, Quail P, Wing R, Dean R, Yu Y, 
Zharkikh A, Shen R, Sahasrabudhe S, Thomas A, Cannings R, Gutin A, Pruss D, Reid J, Tavtigian S, Mitchell J, Eldredge G, Scholl T, Miller RM, Bhatnagar S, Adey N, Rubano T, Tusneem N, Robinson R, Feldhaus J, Macalma T, Oliphant A, Briggs S. 2002. A draft sequence of the rice genome (Oryza sativa L. ssp. Japonica). Science 296:92-100.

Gó mez-Galindo F, Sjoholm I, Rasmusson A, Widell S, Kaack K. 2007. Plant stress physiology: Opportunities and challenges for the food industry. Crit Rev Food Sci Nutr 46:749-763.

Goossens A, Hakkinen ST, Laakso I, Seppanen-Laakso T, Biondi S, Sutter VD, Lammertyn F, Nuutila AM, Soderlund H, Zabeau M, Inze D, Oksman-Caldentey K. 2003. A functional genomics approach toward the understanding of secondary metabolism in plant cells. Proc Natl Acad Sci USA 100:8595-8600.

Görg A, Drews O, Luck C, Weiland F, Weiss W. 2009. 2-DE with IPGs. Electrophoresis 30:S122-S132.

Granier F. 1988. Extraction of plant-proteins for two-dimensional electrophoresis. Electrophoresis 9:712-718.

Greenbaum D, Colangelo C, Williams K, Gerstein M. 2003. Comparing protein abundance and mRNA expression levels on a genomic scale. Genome Biol 4:117.

Griffin TJ, Gygi SP, Ideker T, Rist B, Eng J, Hood L, Aebersold R. 2002. Complementary profiling of gene expression at the transcriptome and proteome levels in Saccharomyces cerevisiae. Mol Cell Proteomics 1:323-333.

Griffin NM, Yu J, Long F, Oh P, Shore S, Li Y, Koziol JA, Schnitzer JE. 2010. Label-free, normalized quantification of complex mass spectrometry data for proteomic analysis. Nat Biotechnol 28: 83-89.

Guerrier L, Righetti PG, Boschetti E. 2008. Reduction of dynamic protein concentration range of biological extracts for the discovery of low-abundance proteins by means of hexapeptide ligand library. Nat Protocols 3:883-890.

Gygi SP, Rochon Y, Franza BR, Aebersold R. 1999. Correlation between protein and mRNA abundance in yeast. Mol Cell Biol 19:1720- 1730 .

Hadley C. 2006. Food allergies on the rise? Determining the prevalence of food allergies, and how quickly it is increasing, is the first step in tackling the problem. EMBO Rep 7:1080-1083.

Heazlewood JL, Durek P, Hummel J, Selbig J, Weckwerth W, Walther D, Schulze WX. 2008. PhosPhAt: A database of phosphorylation sites in Arabidopsis thaliana and a plant-specific phosphorylation site predictor. Nucleic Acids Res 36:D1015-D1021.

Heick J, Fischer M, Kerbach S, Tamm U, Popping B. 2011. Application of a liquid chromatography tandem mass spectrometry method for the simultaneous detection of seven allergenic foods in flour and bread and comparison of the method with commercially available ELISA test kits. J AOAC Int 94:1060-1068.

Heick J, Fischer M, Popping B. 2011. First screening method for the simultaneous detection of seven allergens by liquid chromatography mass spectrometry. $\mathrm{J}$ Chromatogr A 1218:938-943.

Helmy M, Tomita M, Ishihama Y. 2011. OryzaPG-DB: Rice proteome database based on shotgun proteogenomics. BMC Plant Biol 11:63. 
Herdt BW. 2006. Biotechnology in agriculture. Annu Rev Environ Resour 31:265-295.

Herrero M, Simó C, García-Cañ as V, Ibá ñ̃ ez E, Cifuentes A. 2012. Foodomics: MS-based strategies in modern food science and nutrition. Mass Spectrom Rev 31:49-69.

Hertog M, Rudell D, Pedreschi R, Schaffer R, Geeraerd A, Nicolai B, Ferguson I. 2011. Review: Where systems biology meets postharvest. Postharvest Biol Technol 62:223237.

Hesser L. 2006. The Man Who Fed The World: Nobel Peace Prize Laureate Norman Borlaug and His Battle to End World Hunger. Dallas, Texas, USA: Durban House Publishing Company, Inc.

Hirai MY, Yano M, Goodenowe DB, Kanaya S, Kimura T, Awazuhara M, Arita M, Fujiwara T, Saito K. 2004. Integration of transcriptomics and metabolomics for understanding of global responses to nutritional stresses in Arabidopsis thaliana. Proc Natl Acad Sci USA 101:10205-10210.

Houston NL, Fan C, Xiang QY, Schulze JM, Jung R, Boston RS. 2005. Phylogenetic analyses identify 10 classes of the protein disulfide isomerase family in plants, including single-domain PDI-related proteins. Plant Physiol 137:762-778.

Houston NL, Lee DG, Stevenson SE, Ladics GS, Bannon GA, McClain S, Privalle L, Stagg N, Herouet-Guicheney C, MacIntosh SC, Thelen JJ. 2011. Quantitation of soybean allergens using tandem mass spectrometry. J Proteome Res 10:763-773.

Hoving S, Voshol H, Van Oostrum J. 2000. Towards high performance two-dimensional gel electrophoresis using ultrazoom gels. Electrophoresis 21:2617-2621.

Hoving S, Gerrits B, Voshol H, Muller D, Roberts RC, van Oostrum J. 2002. Preparative two-dimensional gel electrophoresis at alkaline $\mathrm{pH}$ using narrow range immobilized $\mathrm{pH}$ gradients. Proteomics 2:127-134.

Illing N, Denby K, Collett H, Shen A, Farrant JM. 2005. The signature of seeds in resurrection plants: A molecular and physiological comparison of desiccation tolerance in seeds and vegetative tissues. Integ Comp Biol 45:771-787.

Ingle RA, Schmidt U, Farrant JM, Mundree SG, Thompson JA. 2007. Proteomic analysis of leaf proteins during dehydration of the resurrection plant Xerophyta viscosa. Plant Cell Environ 30:435-446.

International Rice Genome Sequencing Project. 2005. The map based sequence of the rice genome. Nature 436:793-800.

Isaacson T, Damasceno CMB, Saravanan RS, He Y, Catalá C, Saladié M, Rose JKC. 2006. Sample extraction techniques for enhanced proteomic analysis of plant tissues. Nat Protocol 1:769-774.

Islam N, Campbell PM, Higgins TJV, Hirano H, Akhurst RJ. 2009. Transgenic peas expressing an alpha-amylase inhibitor gene from beans show altered expression and modification of endogenous proteins. Electrophoresis 30:1863-1868.

James C. 2009. Global status of commercialized biotech/GM crops: 2009. Ithaca, NY: ISAAA Briefs 39-2008, 2009, ISAAA.

Jensen ON. 2004. Modification-specific proteomics: Characterization of post-translational modifications by mass spectrometry. Curr Opin Chem Biol 8:33-41. 
Jiang G, Wang Z, Shang H, Yang W, Hu Z, Phillips J, Deng X. 2007. Proteome analysis of leaves from the resurrection plant Boea hygrometrica in response to dehydration and rehydration. Planta 225:1405-1420.

Johann DJ Jr, McGuigan MD, Patel AR, Tomov S, Ross S, Conrads TP, Veenstra TD, Fishman DA, Whiteley GR, Petricoin EF III, Liotta LA. 2004. Clinical proteomics and biomarker discovery. Ann NY Acad Sci 1022:295-305.

Johnson P, Baumgartner S, Aldick T, Bessant C, Giosafatto V, Heick J, Mamone G, O’Connor G, Poms R, Popping B, Reuter A, Ulberth F, Watson A, Monaci L, Mills C. 2011. Current perspectives and recommendations for the development of mass spectrometry methods for the determination of allergens in foods. J AOAC Int 94:18.

Jones JDG, Dangl JL. 2006. The plant immune system. Nature 444:323-329.

Jones AM, Chory J, Dangl JL, Estelle M, Jacobsen SE, Meyerowitz EM, Nordborg M, Weigel D. 2008. The impact of Arabidopsis on human health: Diversifying our portfolio. Cell 133:939-943.

Jorr'in-Novo JV, Maldonado AM, Castillejo MA. 2007. Plant proteome analysis: A 2006 update. Proteomics 7:2947-2962.

Jorr'in-Novo JV, Maldonado AM, Echevarr'ia-Zomeñ o S, Valledor L, Castillejo MA, Curto M, Valero J, Sghaier B, Donoso G, Redondo I. 2009. Plant proteomics update (2007-2008): Second-generation proteomic techniques, an appropriate experimental design, and data analysis to fulfill MIAPE standards, increase plant proteome coverage and expand biological knowledge. J Proteomics 72:285-314.

Karp NA, Lilley KS. 2005. Maximising sensitivity for detecting changes in protein expression: Experimental design using minimal CyDyes. Proteomics 5:3105-3115.

Kasuga M, Liu Q, Miura S, Yamaguchi-Shinozaki K, Shinozaki K. 1999. Improving plant drought, salt, and freezing tolerance by gene transfer of a single stress-inducible transcription factor. Nat Biotechnol 17:287-291.

Kersten B, Agrawal GK, Iwahashi H, Rakwal R. 2006. Plant phosphopro- teomics: A long road ahead. Proteomics 6:5517-5528.

Kersten B, Agrawal GK, Durek P, Neigenfind J, Schulze W, Walther D, Rakwal R. 2009. Plant phosphoproteomics: An update. Proteomics 9:964-988.

Kjeldsen F, Haselmann KF, Budnik BA, Sorensen ES, Zubarev RA. 2003. Complete characterization of posttranslational modification sites in the bovine milk protein $\mathrm{PP}_{3}$ by tandem mass spectrometry with electron capture dissociation as the last stage. Anal Chem 75:2355-2361.

Kline KG, Sussman MR. 2010. Protein quantitation using isotope-assisted mass spectrometry. Annu Rev Biophys 39:291-308.

Kline KG, Barrett-Wilt GA, Sussman MR. 2010. In planta changes in protein phosphorylation induced by the plant hormone abscisic acid. Proc Natl Acad Sci USA 107:15986-15991.

Klose J. 1975. Protein mapping by combined isoelectric focusing and electrophoresis in mouse tissues. A novel approach to testing for induced point mutations in mammals. Humangenetik 26:231-243. 
Kota U, Goshe MB. 2011. Advances in qualitative and quantitative plant membrane proteomics. Phytochemistry 72:1040-1060.

Kuiper HA, Kok EJ, Engel KH. 2003. Exploitation of molecular profiling techniques for GM food safety assessment. Curr Opin Biotechnol 14:238-243.

Lange V, Picotti P, Domon B, Aebersold R. 2008. Selected reaction monitoring for quantitative proteomics: A tutorial. Mol Syst Biol 4:222.

Larré C, Penninck S, Bouchet B, Lollier V, Tranquet O, Denery-Papini S, Guillon F, Rogniaux H. 2010. Brachypodium distachyon grain: Identification and subcellular localization of storage proteins. J Exp Bot 61:1771-1783.

Lee J, Feng J, Campbell K, Scheffler BE, Garrett WM, Thibivilliers S, Stacey G, Naiman DQ, Tucker ML, Pastor-Corrales MA, Cooper B. 2009. Quantitative proteomic analysis of bean plants infected by a virulent and avirulent obligate rust fungus. Mol Cell Proteomics 8:19-31.

Lee J, Jiang W, Qiao Y, Cho YI, Woo MO, Chin JH, Kwon SW, Hong SS, Choi IY, Koh HJ. 2011. Shotgun proteomic analysis for detecting differentially expressed proteins in the reduced culm number rice. Proteomics 11:455-468.

Legrain P, Aebersold R, Archakov A, Bairoch A, Bala K, Beretta L, Bergeron J, Borchers C, Corthals GL, Costello CE, Deutsch EW, Domon B, Hancock W, He F, Hochstrasser D, Marko-Varga G, Salekdeh GH, Sechi S, Snyder M, Srivastava S, Uhlen M, Wu CH, Yamamoto T, Paik YK, Omenn GS. 2011. The human proteome project: Current state and future direction. Mol Cell Proteomics 10:M111.009993.

Lehesranta SJ, Davies HV, Shepherd LVT, Nunan N, McNicol JW, Auriola S, Koistinen KM, Suomalainen S, Kokko HI, Karenlampi SO. 2005. Comparison of tuber proteomes of potato varieties, landraces, and genetically modified lines. Plant Physiol 138:16901699.

Lehmann U, Wienkoop S, Tschoep H, Weckwerth W. 2008. If the anti-body fails - A mass Western approach. Plant J 55:1039-1046.

Liska AJ, Shevchenko A. 2003. Combining mass spectrometry with database interrogation strategies in proteomics. Trends Anal Chem 22:291-298.

Lliso I, Tadeo FR, Phinney BS, Wilkerson CG, Ta'lon M. 2007. Protein changes in the albedo of citrus fruits on postharvest storage. J Agric Food Chem 55:9047-9053.

Lovegrove A, Salt L, Shewry PR. 2009. Establishing substantial equivalence: Proteomics. In: Jones HD, Shewry PR, editors. Transgenic wheat, barley and oats. Methods in molecular biology, Volume 478. Harpenden, Humana Press: John M. Walker.

Luo J, Ning T, Sun Y, Zhu J, Zhu Y, Lin Q, Yang D. 2009. Proteomic analysis of rice endosperm cells in response to expression of hGM-CSF. J Proteome Res 8:829-837.

MacKay VL, Li X, Flory MR, Turcott E, Law GL, Serikawa KA, Xu XL, Lee H, Goodlett DR, Aebersold R, Zhao LP, Morris DR. 2004. Gene expression analyzed by highresolution state array analysis and quantitative proteomics: Response of yeast to mating pheromone. Mol Cell Proteomics 3:478-489.

Mann M, Jensen ON. 2003. Proteomic analysis of post-translational modifications. Nat Biotechnol 21:255-261.

Manza LL, Stamer SL, Ham AJL, Codreanu SG, Liebler DC. 2005. Sample preparation and digestion for proteomic analyses using spin filters. Proteomics 5:1742-1745. 
Marsh E, Alvarez S, Hicks L, Barbazuk WB, Qiu W, Kovacs L, Schachtman D. 2010. Changes in protein abundance during powdery mildew infection of leaf tissues of Cabernet Sauvignon grapevine (Vitis vinifera L.). Proteomics 10:2057-2064.

Matros A, Kaspar S, Witzel K, Mock HP. 2011. Recent progress in liquid chromatographybased separation and label-free quantitative plant proteomics. Phytochemistry 72:963-974.

Matsumoto T, Tanaka T, Sakai H, Amano N, Kanamori H, Kurita K, Kikuta A, Kamiya K, Yamamoto M, Ikawa H, Fujii N, Hori K, Itoh T, Sato K. 2011. Comprehensive sequence analysis of 24,783 barley full-length cDNAs derived from 12 clone libraries. Plant Physiol 156:20-28.

Mayer KF, Martis M, Hedley PE, Simkova H, Liu H, Morris JA, Steuernagel B, Taudien S, Roessner S, Gundlach H, Kubalakova M, Suchankova P, Murat F, Felder M, Nussbaumer T, Graner A, Salse J, Endo T, Sakai H, Tanaka T, Itoh T, Sato K, Platzer M, Matsumoto T, Scholz U, Dolezel J, Waugh R, Stein N. 2011. Unlocking the barley genome by chromosomal and comparative genomics. Plant Cell 23:12491263.

Mechin V, Damerval C, Zivy M. 2007. Total protein extraction with TCA-acetone. In: Thiellement H, Zivy M, Damerval C, Mechin V, editors. Plant proteomics: Methods and protocols. Methods Mol Biol 355:1-8.

Meyer Y, Grosset J, Chartier Y, Cleyetmarel JC. 1988. Preparation by two-dimensional electrophoresis of proteins for antibody=production-Antibodies against proteins whose synthesis is reduced by auxin in tobacco mesophyll protoplasts. Electrophoresis 9:704- 712.

Miller I, Crawford J, Gianazza E. 2006. Protein stains for proteomic applications: Which, when, why? Proteomics 6:5385-5408.

Miller I, Eberini I, Gianazza E. 2010. Other than IPG-DALT: 2-DE variants. Proteomics 10:586-610.

Millstone E, Brunner E, Mayer S. 1999. Beyond 'substantial equivalence'. Nature 401:525526.

Moore JP, Le NT, Brandt WF, Driouich A, Farrant JM. 2009. Towards a systems-based understanding of plant desiccation tolerance. Trends Plant Sci 14:110-117.

Munns R, Tester M. 2008. Mechanisms of salinity tolerance. Ann Rev Plant Biol 59:651681.

Ncube E, Flett BC, Waalwijk C, Viljoen A. 2011. Fusarium spp. and levels of fumonisins in maize produced by subsistence farmers in South Africa. S Afr J Sci 107:1-7.

Newell-McGloughlin M. 2008. Nutritionally improved agricultural crops. Plant Physiol 147:939-953.

Ngara R, Ndimba BK. 2011. Mapping and characterisation of the sorghum cell suspension culture secretome. Afr J Biotechnol 10:253-266.

Ngara R, Ndimba R, Borch-Jensen J, Jensen ON, Ndimba BK. 2012. Identification and profiling of salinity stress-responsive proteins in Sorghum bicolor seedlings. J Proteomics 75:4139-4150.

Nilo R, Saffie C, Lilley K, Baeza-Yates R, Cambiazo V, Campos-Vargas R, Gonzá lez M, Meisel L, Silva H, Orellana A. 2010. Proteomic analysis of peach fruit mesocarp 
softening and chilling injury using difference in gel electrophoresis (DIGE). BMC Genomics 11:43-63.

Nishimura MT, Dangl JL. 2010. Arabidopsis and the plant immune system. Plant J 61:1053-1066.

OECD. 1993. Safety evaluation of foods derived by modern biotechnology: Concepts and principles. Paris: Organisation for Economic $\mathrm{Co}=$ operation and Development.

Oeljeklaus S, Meyer HE, Warscheid B. 2009. Advancements in plant proteomics using quantitative mass spectrometry. J Proteomics 72:545- 554.

O'Farrell PH. 1975. High resolution two-dimensional electrophoresis of proteins. J Biol Chem 250:4007-4021.

Oliver MJ, Wood AJ, O’Mahony P. 1998. "To dryness and beyond"- preparation for the dried state and rehydration in vegetative desiccation-tolerant plants. Plant Growth Reg 24:193-201.

Oliver MJ, Jain R, Balbuena TS, Agrawal GK, Gasulla F, Thelen JJ. 2011. Proteome analysis of leaves of the desiccation-tolerant grass, Sporobolus stapfianus. Phytochemistry 72:1273-1284.

Palmblad M, Bindschedler LV, Cramer R. 2007. Quantitative proteomics using uniform (15)N-labeling, MASCOT, and the trans-proteomic pipeline. Proteomics 7:34623469 .

Palmisano G, Antonacci D, Larsen MR. 2010. Glycoproteomic profile in wine: A sweet molecular renaissance. J Proteome Res 9:6148-6159.

Paterson AH, Bowers JE, Bruggmann R, Dubchak I, Grimwood J, Gundlach H, Haberer G, Hellsten U, Mitros T, Poliakov A, Schmutz J, Spannagl M, Tang H, Wang X, Wicker T, Bharti AK, Chapman J, Feltus FA, Gowik U, Grigoriev IV, Lyons E, Maher CA, Martis M, Narechania A, Otillar RP, Penning BW, Salamov AA, Wang Y, Zhang L, Carpita NC, Freeling M, Gingle AR, Hash CT, Keller B, Klein P, Kresovich S, McCann MC, Ming R, Peterson DG, Mehboobur R, Ware D, Westhoff P, Mayer KF, Messing J, Rokhsar DS. 2009. The Sorghum bicolor genome and the diversification of grasses. Nature 457:551-556.

Pedreschi R, Vanstreels E, Carpentier S, Robben J, Noben JP, Hertog M, Lammertyn J, Vanderleyden J, Swenen R, Nicolai B. 2007. Proteomic analysis of core breakdown disorder in conference pears (Pyrus communis L). Proteomics 7:2083-2099.

Pedreschi R, Hertog M, Robben J, Lilley K, Nicolä̈ B. 2009. Differential protein expression of conference pear slices submitted to extreme gas concentrations. J Agric Food Chem 57:6977-7004.

Pedreschi R, Hertog M, Lilley K, Nicolai B. 2010. Proteomics for the food industry: Opportunities and challenges. Crit Rev Food Sci Nutrit 50:680-692.

Picariello G, Mamone G, Addeo F, Ferranti P. 2011. The frontiers of mass spectrometrybased techniques in food allergenomics. J Chromatogr A. 1218:7386-7398.

Podell S, Gribskov M. 2004. Predicting N-terminal myristoylation sites in plant proteins. BMC Genomics 5:37.

Popluechai S, Froissard M, Jolivet P, Breviario D, Gatehouse AMR, Donnell AGO, Chardot T, Kohli A. 2011. Jatrophus curcas oil body proteome and oleosins: L-form JeOle3 as a potential phylogenetic marker. Plant Physiol Biohem 49:352-356. 
Porter JR, Semenov MS. 2005. Crop responses to climatic variation. Philos Trans R Soc B 360:2021-2035.

Quirino BF, Candido ES, Campos PF, Franco OL, Krü ger RH. 2010. Proteomic approaches to study plant-pathogen interactions. Phytochemistry 71:351-362.

Rakwal R, Agrawal GK. 2003. Rice proteomics: Current status and future perspectives. Electrophoresis 24:3378-3389.

Rampitsch C, Bykova NV. 2012. Proteomics and plant disease: Advances in combating a major threat to the global food supply. Proteomics 12:673-690.

Ranjithakumari BD, editor. 2008. Plant proteomics. In: India: A. P. H. Publication Corporation.

Remmerie N, De Vijlder T, Laukens K, Dang TH, Lemiè re F, Mertens I, Valkenborg D, Blust R, Witters E. 2011. Next generation functional proteomics in non-model plants: A survey on techniques and applications for the analysis of protein complexes and post-translational modifications. Phytochemistry 72:1192-1218.

Ren Y, Lv J, Wang H, Li L, Peng Y, Qu LJ. 2009. A comparative proteomics approach to detect unintended effects in transgenic Arabidopsis. J Genet Genomics 36:629-639.

Renuse S, Chaerkady R, Pandey A. 2011. Proteogenomics. Proteomics 11:620-630.

Reynolds MP, Borlaug NE. 2006. Applying innovations and new technologies for international collaborative wheat improvement. J Agric Sci 144:95-110.

Righetti PG, Boschetti E. 2008. The ProteoMiner and the FortyNiners: Searching for gold nuggets in the proteomic arena. Mass Spectrom Rev 27:596-608.

Righetti PG, Boschetti E, Lomas L, Citterio A. 2006. Protein equalizer technology: The quest for a "democratic proteome". Proteomics 6:3980-3992.

Righetti PG, Antonioli P, Simo` C, Citterio A. 2008. Gel-based proteomics. In: Agrawal GK, Rakwal R, editors. Plant proteomics: Technologies, strategies, and applications. Hoboken, NJ: John Wiley \& Sons, Inc. pp 11-30.

Righetti PG, Fasoli E, Boschetti E. 2011. Combinatorial peptide ligand libraries: The conquest of the 'hidden proteome' advances at great strides. Electrophoresis 332:960-966.

Rose JKC, Bashir S, Giovannoni JJ, Jahn MM, Saravanan RS. 2004. Tackling the plant proteome: Practical approaches, hurdles and experimental tools. Plant J 39:715-733.

Rossignol M, Peltier JB, Mock HP, Matros A, Maldonado AM, Jorrín JV. 2006. Plant proteome analysis: A 2004-2006 update. Proteomics 6:5529-5548.

Ruebelt MC, Leimgruber NK, Lipp M, Reynolds TL, Nemeth MA, Astwood JD, Engel KH, Jany KD. 2006a. Application of two-dimensional gel electrophoresis to interrogate alterations in the proteome of gentically modified crops. 1. Assessing analytical validation. J Agric Food Chem 54:2154-2161.

Ruebelt MC, Lipp M, Reynolds TL, Astwood JD, Engel KH, Jany KD. 2006b. Application of two-dimensional gel electrophoresis to interrogate alterations in the proteome of gentically modified crops. 2. Assessing natural variability. J Agric Food Chem 54:2162-2168.

Ruebelt MC, Lipp M, Reynolds TL, Schmuke JJ, Astwood JD, DellaPenna D, Engel KH, Jany KD. 2006c. Application of two-dimensional gel electrophoresis to 
interrogate alterations in the proteome of gentically modified crops. 3 . Assessing unintended effects. J Agric Food Chem 54:2169-2177.

Saito K, Hirai MY, Yonekura-Sakakibara K. 2008. Decoding genes with coexpression networks and metabolomics-'majority report by precogs'. Trends Plant Sci 13:3643.

Samaj J, Thelen JJ. 2007. Plant proteomics. In: Samaj J, Thelen JJ, editors. USA: Springer.

Sanders WS, Wang N, Bridges SM, Malone BM, Dandass YS, McCarthy FM, Nanduri B, Lawrence ML, Burgess SC. 2011. The proteogenomic mapping tool. BMC Bioinformatics 12:115.

Saravanan RS, Rose JKC. 2004. A critical evaluation of sample extraction techniques for enhanced proteomic analysis of recalcitrant plant tissues. Proteomics 4:25222532.

Schaff JE, Mbeunkui F, Blackburn K, Bird DM, Goshe MB. 2008. SILIP: A novel stable isotope labeling method for in planta quantitative proteomic analysis. Plant $\mathrm{J}$ $56: 840-854$.

Scheele GA. 1975. Two-dimensional gel analysis of soluble proteins. Characterization of guinea pig exocrine pancreatic proteins. $\mathrm{J}$ Biol Chem 250:5375-5385.

Schmidt H, Gelhaus C, Latendorf T, Nebendahl M, Petersen A, Krause S, Leippe M, Becker WM, Janssen O. 2009. 2-D DIGE analysis of the proteome of extracts from peanut variants reveals striking differences in major allergen contents. Proteomics 9:3507-3521.

Schnable PS, Ware D, Fulton RS, Stein JC, Wei F, Pasternak S, Liang C, Zhang J, Fulton L, Graves TA, Minx P, Reily AD, Courtney L, Kruchowski SS, Tomlinson C, Strong C, Delehaunty K, Fronick C, Courtney B, Rock SM, Belter E, Du F, Kim K, Abbott RM, Cotton M, Levy A, Marchetto P, Ochoa K, Jackson SM, Gillam B, Chen W, Yan L, Higginbotham J, Cardenas M, Waligorski J, Applebaum E, Phelps L, Falcone J, Kanchi K, Thane T, Scimone A, Thane N, Henke J, Wang T, Ruppert J, Shah N, Rotter K, Hodges J, Ingenthron E, Cordes M, Kohlberg S, Sgro J, Delgado B, Mead K, Chinwalla A, Leonard S, Crouse K, Collura K, Kudrna D, Currie J, He R, Angelova A, Rajasekar S, Mueller T, Lomeli R, Scara G, Ko A, Delaney K, Wissotski M, Lopez G, Campos D, Braidotti M, Ashley E, Golser W, Kim H, Lee S, Lin J, Dujmic Z, Kim W, Talag J, Zuccolo A, Fan C, Sebastian A, Kramer M, Spiegel L, Nascimento L, Zutavern T, Miller B, Ambroise C, Muller S, Spooner W, Narechania A, Ren L, Wei S, Kumari S, Faga B, Levy MJ, McMahan L, Van Buren P, Vaughn MW, Ying K, Yeh CT, Emrich SJ, Jia Y, Kalyanaraman A, Hsia AP, Barbazuk WB, Baucom RS, Brutnell TP, Carpita NC, Chaparro C, Chia JM, Deragon JM, Estill JC, Fu Y, Jeddeloh JA, Han Y, Lee H, Li P, Lisch DR, Liu S, Liu Z, Nagel DH, McCann MC, SanMiguel P, Myers AM, Nettleton D, Nguyen J, Penning BW, Ponnala L, Schneider KL, Schwartz DC, Sharma A, Soderlund C, Springer NM, Sun Q, Wang H, Waterman M, Westerman R, Wolfgruber TK, Yang L, Yu Y, Zhang L, Zhou S, Zhu Q, Bennetzen JL, Dawe RK, Jiang J, Jiang N, Presting GG, Wessler SR, Aluru S, Martienssen RA, Clifton SW, McCombie WR, Wing RA, Wilson 
RK. 2009. The B73 maize genome: Complexity, diversity, and dynamics. Science 326:1112-1115.

Schulze WX. 2010. Proteomics approaches to understand protein phosphorylation in pathway modulation. Curr Opin Plant Biol 13:280- 287.

Seng P, Drancourt M, Gouriet F, La Scola B, Fournier PE, Rolain JM, Raoult D. 2009. Ongoing revolution in bacteriology: Routine identification of bacteria by matrix-assisted laser desorption ionization time-of-flight mass spectrometry. Clin Infect Dis 49:543-551.

Sharma N, Hotte N, Rahman MH, Mohammadi M, Deyholos MK, Kav NN. 2008. Towards identifying Brassica proteins involved in mediating resistance to Leptosphaeria maculans: A proteomics-based approach. Proteomics 8:3516-3535. Shefcheck KJ, Musser SM. 2004. Confirmation of the allergenic peanut protein, Arah1, in a model food matrix using liquid chromatography/ tandem mass spectrometry (LC/MS/MS). J Agric Food Chem 52: 2785-2790.

Shefcheck KJ, Callahan JH, Musser SM. 2006. Confirmation of peanut protein using peptide markers in dark chocolate using liquid chromatography-tandem mass spectrometry (LC-MS/MS). J Agric Food Chem 54:7953-7959.

Shevchenko A, Sunyaev S, Loboda A, Shevchenko A, Bork P, Ens W, Standing KG. 2001. Charting the proteomes of organisms with unsequenced genomes by MALDI-quadrupole time-of-flight mass spectrometry and BLAST homology searching. Anal Chem 73:1917-1926.

Shulaev V, Sargent DJ, Crowhurst RN, Mockler TC, Folkerts O, Delcher AL, Jaiswal P, Mockaitis K, Liston A, Mane SP, Burns P, Davis TM, Slovin JP, Bassil N, Hellens RP, Evans C, Harkins T, Kodira C, Desany B, Crasta OR, Jensen RV, Allan AC, Michael TP, Setubal JC, Celton JM, Rees DJ, Williams KP, Holt SH, Ruiz Rojas JJ, Chatterjee M, Liu B, Silva H, Meisel L, Adato A, Filichkin SA, Troggio M, Viola R, Ashman TL, Wang H, Dharmawardhana P, Elser J, Raja R, Priest HD, Bryant DW Jr, Fox SE, Givan SA, Wilhelm LJ, Naithani S, Christoffels A, Salama DY, Carter J, Lopez Girona E, Zdepski A, Wang W, Kerstetter RA, Schwab W, Korban SS, Davik J, Monfort A, Denoyes-Rothan B, Arus P, Mittler R, Flinn B, Aharoni A, Bennetzen JL, Salzberg SL, Dickerman AW, Velasco R, Borodovsky M, Veilleux RE, Folta KM. 2011. The genome of woodland strawberry (Fragaria vesca). Nat Genet 43:109-116.

Singh RP, Hodson DP, Huerta-Espino J, Jin Y, Njau P, Wanyera R, Herrera-Foessel SA, Ward RW. 2008. Will stem rust destroy the world's wheat crop? Adv Agron 98:271-309.

Soderlund C, Descour A, Kudrna D, Bomhoff M, Boyd L, Currie J, Angelova A, Collura K, Wissotski M, Ashley E, Morrow D, Fernandes J, Walbot V, Yu Y. 2009. Sequencing, mapping, and analysis of 27,455 maize full-length cDNAs. PLoS Genet 5:e1000740.

Soltis DE, Soltis PS. 1999. Polyploidy: Recurrent formation and genome evolution. Trends Ecol Evol 14:348-352. 
Sonah H, Deshmukh RK, Singh VP, Gupta DK, Singh NK, Sharma TR. 2011. Genomic resources in horticultural crops: Status, utility and challenges. Biotechnol Adv 29:199-209.

Sorda G, Banse M, Kemfert C. 2010. An overview of biofuel policies across the world. Energy Policy 38:6977-6988.

Souchelnytskyi S. 2008. Proteomics in context of systems biology. In: Agrawal GK, Rakwal R, editors. Plant proteomics: Technologies, strategies, and applications. Hoboken, NJ: John Wiley \& Sons, Inc. pp 695-709.

Specht M, Stanke M, Terashima M, Naumann-Busch B, Janssen I, Hohner R, Hom EF, Liang C, Hippler M. 2011. Concerted action of the new genomic peptide finder and AUGUSTUS allows for automated proteogenomic annotation of the Chlamydomonas reinhardtii genome. Proteomics 11:1814-1823.

Srinivas PR, Kramer BS, Srivastava S. 2001. Trends in biomarkers research for cancer. Lancet Oncol 2:698-704.

Strange RN, Scott PR. 2005. Plant disease: A threat to global food security. Annu Rev Phytopathol 43:83-116.

Sudhakar Johnson T, Eswaran N, Sujatha M. 2011. Molecular approaches to improvement of Jatropha curcas Linn. as a sustainable energy crop. Plant Cell Rep 30:1573-1591.

Sun Q, Zybailov B, Majeran W, Friso G, Olinares PD, van Wijk KJ. 2009. PPDB, the plant proteomics database at Cornell. Nucleic Acids Res 37:D969-D974.

Tathman AS, Shewry PR. 2008. Allergens to wheat and related cereals. Clin Exp Allergy 38:1712-1726.

Teshima R, Nakamura R, Satoh R, Nakamura R. 2010. 2D-DIGE analysis of rice proteins from different cultivars. Regul Toxicol Pharmacol 58:S30-S35.

The Arabidopsis Genome Initiative. 2000. Analysis of the genome sequence of the flowering plant Arabidopsis thaliana. Nature 408: 796-815.

Thiellement H. 2007. Plant proteomics: Methods and protocols. In: Thiellement H, Zivy M, Damerval C, Mechin V, editors. Humana Press.

Thines M, Choi YJ, Kemen E, Ploch S, Holub EB, Shin HD, Jones JDG. 2009. A new species of Albugo parasitic to Arabidopsis thaliana reveals new evolutionary patterns in white blister rusts (Albuginaceae). Persoonia 22:123-128.

Tian Q, Stepaniants SB, Mao M, Weng L, Feetham MC, Doyle MJ, Yi EC, Dai H, Thorsson V, Eng J, Goodlett D, Berger JP, Gunter B, Linseley PS, Stoughton RB, Aebersold R, Collins SJ, Hanlon WA, Hood LE. 2004. Integrated genomic and proteomic analyses of gene expression in mammalian cells. Mol Cell Proteomics 3:960-969.

Tolonen AC, Haas W, Chilaka AC, Aach J, Gygi SP, Church GM. 2011. Proteome-wide systems analysis of a cellulosic biofuel-producing microbe. Mol Syst Biol 7:461. DOI: 10.1038/MSB.2010.116

Tomer KB, Moseley MA, Deterding LJ, Parker CE. 1994. Capillary liquid chromatography/mass spectrometry. Mass Spectrom Rev 13: 431-457.

Tschirley D, Nijhoff JJ, Arlindo P, Mwinga B, Weber MT, Jayne TS. 2004. Anticipating and responding to drought emergencies in Southern Africa: Lessons 
from the 2002-2003 experience. Paper prepared for NEPAD 22-25, November 2004. Kenya: Nairobi.

Unlu M, Morgan ME, Minden JS. 1997. Difference gel electrophoresis: A single gel method for detecting changes in protein extracts. Electrophoresis 18:2071-2077.

Vasan RS. 2006. Biomarkers of cardiovascular disease: Molecular basis and practical considerations. Circulation 113:2335-2362.

Velasco R, Zharkikh A, Affourtit J, Dhingra A, Cestaro A, Kalyanaraman A, Fontana P, Bhatnagar SK, Troggio M, Pruss D, Salvi S, Pindo M, Baldi P, Castelletti S, Cavaiuolo M, Coppola G, Costa F, Cova V, Dal Ri A, Goremykin V, Komjanc M, Longhi S, Magnago P, Malacarne G, Malnoy M, Micheletti D, Moretto M, Perazzolli M, Si-Ammour A, Vezzulli S, Zini E, Eldredge G, Fitzgerald LM, Gutin N, Lanchbury J, Macalma T, Mitchell JT, Reid J, Wardell B, Kodira C, Chen Z, Desany B, Niazi F, Palmer M, Koepke T, Jiwan D, Schaeffer S, Krishnan V, Wu C, Chu VT, King ST, Vick J, Tao Q, Mraz A, Stormo A, Stormo K, Bogden R, Ederle D, Stella A, Vecchietti A, Kater MM, Masiero S, Lasserre P, Lespinasse Y, Allan AC, Bus V, Chagne D, Crowhurst RN, Gleave AP, Lavezzo E, Fawcett JA, Proost S, Rouze P, Sterck L, Toppo S, Lazzari B, Hellens RP, Durel CE, Gutin A, Bumgarner RE, Gardiner SE, Skolnick M, Egholm M, Van de Peer Y, Salamini F, Viola R. 2010. The genome of the domesticated apple (Malus $x$ domestica Borkh.). Nat Genet 42:833-839.

Vertommen A, Møller AL, Cordewener JH, Swennen R, Panis B, Finnie C, America AH, Carpentier SC. 2011a. A workflow for peptide-based proteomics in a poorly sequenced plant: A case study on the plasma membrane proteome of banana. $J$ Proteomics 74:1218-1229.

Vertommen A, Panis B, Swennen R, Carpentier SC. 2011b. Challenges and solutions for the identification of membrane proteins in non-model plants. $J$ Proteomics 74:1165-1181.

Wang WW, Meng B, Ge XM, Song SH, Yang Y, Yu XM, Wang L, Hu SN, Liu SQ, Yu J. 2008. Proteomic profiling of rice embryos from a hybrid rice cultivar and its parental lines. Proteomics 8:4808-4821.

Wang K, Han X, Dong K, Gao L, Li H, Ma W, Yan Y, Ye X. 2010. Characterization of seed proteome in Brachypodium distachyon. J Cereal Sci 52:177-186.

Ward DC, White DC. 2002. The new 'omics era. Curr Opin Biotechnol 13:11-13.

Ward TJ, Clear RM, Rooney AP, O’Donnell K, Gaba D, Patrick S, Starkey DE, Gilbert J, Geiser DM, Nowicki TW. 2008. An adaptive evolutionary shift in Fusarium head blight pathogen populations is driving the rapid spread of more toxigenic Fusarium graminearum in North America. Fungal Genet Biol 45:473-484.

Washburn MP, Ulaszek R, Deciu C, Schieltz DM, Yates JR. 2002. Analysis of quantitative proteomic data generated via multidimensional protein identification technology. Anal Chem 74:1650-1657.

Weber D, Polenta G, Lau BPY, Godefroy SB. 2009. Detection and confirmation of food allergen using mass spectrometric techniques: Characterization of allergens in hazelnut using ESI and MALDI mass spectrometry. Intentional Unintentional Contam Food Feed 1020: 153-182. 
Weckwerth W. 2011. Green systems biology-From single genomes, proteomes and metabolomes to ecosystems research and biotechnology. J Proteomics 75:284305.

Weckwerth W, Baginsky S, van Wijk K, Heazlewood JL, Millar H. 2008. The multinational Arabidopsis steering subcommittee for proteomics assembles the largest proteome database resource for plant systems biology. J Proteome Res 7:4209-4210.

Wienkoop S, Morgenthal K, Wolschin F, Scholz M, Selbig J, Weckwerth W. 2008. Integration of metabolomic and proteomic phenotypes: Analysis of data covariance dissects starch and RFO metabolism from low and high temperature compensation response in Arabidopsis thaliana. Mol Cell Proteomics 7:1725-1736.

Wienkoop S, Baginsky S, Weckwerth W. 2010. Arabidopsis thaliana as a model organism for plant proteome research. J Proteomics 73:2239- 2248.

Wilkins MR, Sanchez JC, Gooley AA, Appel RD, Humphery-Smith I, Hochstrasser DF, Williams KL. 1995. Progress with proteome projects: Why all proteins expressed by a genome should be identified and how to do it. Biotechnol Genet Eng Rev 13:S19-S50.

Wilson ID, Nicholson JK, Castro-Perez J, Granger JH, Johnson KA, Smith BW, Plumb RS. 2005. High resolution "ultra-performance" liquid chromatography coupled to a TOF mass spectrometry as a tool for differential metabolic pathway profiling in functional genomic studies. J Proteome Res 4:591-598.

Wisniewski JR, Zougman A, Nagaraj N, Mann M. 2009. Universal sample preparation method for proteome analysis. Nat Methods 6:359-362.

Witze ES, Old WM, Resing KA, Ahn NG. 2007. Mapping protein posttranslational modifications with mass spectrometry. Nat Methods 4:798-806.

Wolters DA, Washburn MP, Yates JR. 2001. An Automated multidimensional protein identification technology for shotgun proteomics. Anal Chem 73:5683-5690.

World Food Summit. 1996. http://www.fao.org/wfs/index_en.htm

Xu X, Pan S, Cheng S, Zhang B, Mu D, Ni P, Zhang G, Yang S, Li R, Wang J, Orjeda G, Guzman F, Torres M, Lozano R, Ponce O, Martinez D, De la Cruz G, Chakrabarti SK, Patil VU, Skryabin KG, Kuznetsov BB, Ravin NV, Kolganova TV, Beletsky AV, Mardanov AV, Di Genova A, Bolser DM, Martin DM, Li G, Yang Y, Kuang H, Hu Q, Xiong X, Bishop GJ, Sagredo B, Mejia N, Zagorski W, Gromadka R, Gawor J, Szczesny P, Huang S, Zhang Z, Liang C, He J, Li Y, He Y, Xu J, Zhang Y, Xie B, Du Y, Qu D, Bonierbale M, Ghislain M, Herrera Mdel R, Giuliano G, Pietrella M, Perrotta G, Facella P, O’Brien K, Feingold SE, Barreiro LE, Massa GA, Diambra L, Whitty BR, Vaillancourt B, Lin H, Massa AN, Geoffroy M, Lundback S, DellaPenna D, Buell CR, Sharma SK, Marshall DF, Waugh R, Bryan GJ, Destefanis M, Nagy I, Milbourne D, Thomson SJ, Fiers M, Jacobs JM, Nielsen KL, Sonderkaer M, Iovene M, Torres GA, Jiang J, Veilleux RE, Bachem CW, de Boer J, Borm T, Kloosterman B, van Eck H, Datema E, Hekkert BL, Goverse A, van Ham RC, Visser RG. 2011. Genome sequence and analysis of the tuber crop potato. Nature 475:189-195. 
Yang F, Jensen JD, Svensson B, Jørgensen HJ, Collinge DB, Finnie C. 2010. Analysis of early events in the interaction between Fusarium graminearum and the susceptible barley (Hordeum vulgare) cultivar Scarlett. Proteomics 10:3748-3755.

Yates JR III, Ruse CI, Nakorchevsky A. 2009. Proteomics by mass spectrometry: Approaches, advances, and applications. Annu Rev Biomed Eng 11:49-79.

Yu J, Hu S, Wang J, Wong GK, Li S, Liu B, Deng Y, Dai L, Zhou Y, Zhang X, Cao M, Liu J, Sun J, Tang J, Chen Y, Huang X, Lin W, Ye C, Tong W, Cong L, Geng J, Han Y, Li L, Li W, Hu G, Huang X, Li W, Li J, Liu Z, Li L, Liu J, Qi Q, Liu J, Li L, Li T, Wang X, Lu H, Wu T, Zhu M, Ni P, Han H, Dong W, Ren X, Feng X, Cui P, Li X, Wang H, Xu X, Zhai W, Xu Z, Zhang J, He S, Zhang J, Xu J, Zhang K, Zheng X, Dong J, Zeng W, Tao L, Ye J, Tan J, Ren X, Chen X, He J, Liu D, Tian W, Tian C, Xia H, Bao Q, Li G, Gao H, Cao T, Wang J, Zhao W, Li P, Chen W, Wang X, Zhang Y, Hu J, Wang J, Liu S, Yang J, Zhang G, Xiong Y, Li Z, Mao L, Zhou C, Zhu Z, Chen R, Hao B, Zheng W, Chen S, Guo W, Li G, Liu S, Tao M, Wang J, Zhu L, Yuan L, Yang H. 2002. A draft sequence of the rice genome (Oryza sativa L. ssp. Indica). Science 296:79-92.

Yu YQ, Gilar M, Lee PJ, Bouvier ESP, Gebler JC. 2003. Enzyme-friendly, mass spectrometry-compatible surfactant for in-solution enzymatic digestion of proteins. Anal Chem 75:6023-6028.

Zargar SM, Nazir M, Cho K, Kim DW, Jones OAH, Sarkar A, Agrawal SB, Shibato J, Kubo A, Jwa NS, Agrawal GK, Rakwal R. 2011. Impact of climatic changes on crop agriculture: OMICS for sustainability and next-generation crops. In: Benkeblia N, editor. Sustainable agriculture and new biotechnologies, Chapter 19. Boca Raton, FL: CRC Press. pp 454- 473.

Zolla L, Rinalducci S, Antonioli P, Righetti PG. 2008. Proteomics as a complementary tool for identifying unintended side effects occurring in transgenic maize seeds as a result of genetic modifications.

J Proteome Res 7:1850-1861. 